\title{
Sensory responses of descending brain neurons in the walking cricket, Gryllus bimaculatus
}

Accepted: 8 November 2000 / Published online: 24 January 2001 (C) Springer-Verlag 2001 thoracic ganglia $\cdot P S T H$ post-stimulus-time histogram - $S O G$ suboesophageal ganglion . $T 1,2,3$ thoracic ganglion 1,2 , or $3 \cdot t A P$ time of occurrence of an action potential

\section{Introduction}

Animals cope with stimuli of various modalities encountered while performing different behaviors. Stimuli can fall into different categories. They may be attractive, like the calling song of a male cricket (Regen 1913; Thorson et al. 1982), or they may elicit escape responses if they resemble signals produced by a potential predator (Camhi et al. 1978; Hoerner 1992; Pollack and Hoy 1989; Thorson et al. 1982). However, the behavioral reaction of the animal depends not only on the stimulus category, but also on the context in which it is encountered (Nolen and Hoy 1984; Ritzman et al. 1980). How is this reflected in the activity of the central nervous system?

The insect brain receives input of different sensory modalities that converge onto several separate networks thought to extract behaviorally relevant features. Some of these are the direction of movement (Borst and Egelhaaf 1990; Hassenstein and Reichardt 1956) or the detection of a target (e.g., Egelhaaf et al. 1993; Gilbert and Strausfeld 1991; Strausfeld 1991; Warzecha et al. 1993). In crickets, a network of local brain neurons serves to recognize the pattern of the conspecific song (Schildberger 1984b). The locust ocellar system is regarded as important for flight stabilization (Rowell 1993). Furthermore, it has been shown that the interactions of different modalities in different neuronal subsystems influence the behavior in several insects (e.g., Boehm et al. 1991; Robert and Rowell 1992a, 1992b; Schildberger 1984a; Stout et al. 1987; Weber et al. 1987; Zeiner and Tichy 1998). Thus, the systems mentioned above, and various other systems, together may determine the choice of the appropriate behavior to be performed in a given situation.
E. M. Staudacher

University of Michigan, Advanced Technology Laboratories, Ann Arbor, MI 48109-2110, USA

E-mail: staud@umich.edu

Tel.: + 1-734-764-5154

Fax: + 1-734-763-1260 
In insects, descending neurons connect the brain with the ganglia of the ventral nerve cord. As their number is relatively small (ca. 200-300 pairs) compared to the brain and thoracic neurons, they form a bottleneck for the multitude of sensory information converging onto the brain. Together, their summed activity may largely control the behavior of the animal. In grasshoppers and crickets, identified descending neurons are necessary and sufficient to induce singing under some, but not all, conditions (Hedwig 1994, 1996, 2000). In crickets, a command-like descending neuron for walking (Boehm and Schildberger 1992), and another group of descending cells which seems to be important for determining rotational velocity (Staudacher and Schildberger 1998) have been found. A number of ultrasound-sensitive descending interneurons have been reported to be highly active in flying crickets and probably mediate negative phonotaxis (Brodfuehrer and Hoy 1989, 1990). In a fly, the direct coupling of specific visual descending neurons to flight motor neurons has been reported (Gronenberg and Strausfeld 1992; Gronenberg et al. 1995). This seems to serve as a fast circuit for pursuing small, fast-moving targets by the fly (Milde and Strausfeld 1986; Strausfeld and Gronenberg 1990). In flying locusts, a large descending neuron, DCMD, which responds vigorously upon approach to looming objects, is important for mediating collision-avoidance (Gabbiani et al. 1999; Rind and Simmons 1999). Several descending neurons in locusts have been shown to partially overlap in their response characteristics to various combinations of wind and wide-field visual stimuli (e.g., Hensler 1992b; Rowell and Reichert 1986; Simmons 1980a). Therefore, it is assumed that they contribute to flight stabilization as a population of cells, as assumed for descending brain neuron activity in walking locusts (Kien 1983).

In this study, descending brain neurons (DBN) are described morphologically and their response characteristics are reported for stimuli of different categories. This allowed investigating whether the same cell represents stimuli of different categories (e.g., positive taxis versus negative taxis) in the same way. Furthermore, it allowed investigating if and how categorial responses depend on behavioral context (e.g., walking or standing). The results shed some light on the coding of behavior by descending neurons. Preliminary accounts of this study were published in abstract form (Staudacher 1994).

\section{Materials and methods}

Only a short description of the experimental procedures is given here, as the experimental setup and procedures have already been described in detail (Staudacher and Schildberger 1998). Adult female Gryllus bimaculatus DeGeer from a laboratory stock were used at the age of 14-28 days. The neck of the animal was glued to an inverted yoke in a manner that allowed the animal to freely move all legs and other appendages. The connectives between suboesophageal and first thoracic ganglion (cervical or neck connectives) were exposed from the dorsal side and stabilized with a silver platform to allow intracellular recording in the axons of descending cells. The animals were positioned on the top of a hollow Styrofoam ball supported by air bearings. When the animal moved its legs, it moved the ball. Thus, the movement of the ball, which was detected by an infrared camera, represented the intended walking direction and speed of the animal which in fact remained stationary. A microprocessor transformed the camera signals into DC signals, representing the translational and rotational velocities. Experiments were performed under darkroom conditions. Vertical black and white stripes (width $25^{\circ}$ ) could be projected onto a circular curtain surrounding the animal. Turning the projection of a static grating On and Off allowed assessment of the type of illumination change to which the cells responded, although the receptive fields were not known. Furthermore, at other times the grating was moved to the left or right with contrast frequencies up to $11 \mathrm{~Hz}$. A phototransistor on the curtain monitored if the pattern was turned On or Off and any movement of the grating. Its signal represents the visual stimulus in recordings and subsequent graphs. Two speakers situated in front of the animal $50^{\circ}$ left and right of the midline, allowed presentation of acoustic stimuli composed of chirps presented at a rate of $2 \mathrm{~Hz}$. Each chirp consisted of four syllables of $20 \mathrm{~ms}$ duration separated by $20 \mathrm{~ms}$ pauses modeled after the natural calling songs of males of this species. Carrier frequencies of $5 \mathrm{kHz}$ were used to approximate a conspecific male's song and $20 \mathrm{kHz}$ to approximate the sonar of a flying bat, thus eliciting positive and negative phonotaxis respectively. Air puffs with a maximum velocity of $2 \mathrm{~m} \mathrm{~s}^{-1}$ were directed via a nozzle at the cerci of the animal. They were used to mimic the approaching tongue of striking a toad. Usually, three consecutive pulses, each $100 \mathrm{~ms}$ in duration, were delivered with a frequency of $2 \mathrm{~Hz}$. The air puffs may also have reached mechanosensory structures other than those of the cerci. Data were recorded on a tape recorder (Racal Store 7 DS) and evaluated off-line using various programs on a Macintosh computer (SuperScope; Excel 98; StatView 4.0; GB-Stat 5.0.4). Neurons were stained with Lucifer Yellow or Neurobiotin and detected with the PAP method (Taghert et al. 1982) or the ABC method (Horikawa and Armstrong 1988). In both cases DAB served as chromogen. Anatomical descriptions refer to the embryonal neuraxis (Boyan et al. 1993) and cells are named according to Staudacher (1998). The terms ipsilateral and contralateral refer to the location of the soma of the recorded interneuron in the brain, unless otherwise stated.

\section{Results}

\section{General results}

In this cricket, the somata of the approximately 200 pairs of DBNs are located in different clusters of the rind of the brain (Staudacher 1998). Recordings of seven of these descending cells are presented here. Descending brain neurons are usually classified according to their arborization patterns in the brain. The data presented here, show that both major classes, i.e., ipsi- and contralateral, descending brain neurons can be further subdivided into four major morphological types with regard to their branching patterns in the ganglia of the ventral nerve cord. Type I cells (e.g., Fig. 6A; DBNi5n-1) have arborizations on the ipsilateral side of their axon in the medial parts of the suboesophageal ganglion (SOG) and the thoracic ganglia (T1, T2, T3). Type II neurons have only axon ipsilateral arborizations including one prominent branch, which runs towards the 
root of the large leg nerve (N5) in each thoracic ganglion. Depending on whether they arborize in the SOG and extend into the abdominal ganglia this group can be further subdivided into four subtypes (IIa-d: Fig. 5A, DBNi5 neurons; IIa: Fig. 4A, DBNc5-4; IId: Fig. 7A, DBNc5-5). Type III neurons have bilateral medial arborizations in the SOG and the thoracic ganglia and prominent arborizations extending towards the roots of N5 ipsi- and contralateral to their axon (Fig. 3A, DBNc4-1). A type IV neuron, represented by DBNc4-2 (Fig. 2A) has bilateral median branches in SOG and T1-3 and an axon ipsilateral branch reaching towards the root of $\mathrm{N} 5$ in $\mathrm{T} 1$ and $\mathrm{T} 2$, but an axon contralateral one in T3. More data are needed to judge if cell types I, III, and IV can be subdivided in the same way as the type II neurons.

A summary of the physiological data is given in Table 1. Except for one cell (DBNi1-3: Fig. 1), the DBNs were not active when the animal was standing and no stimulus was being presented. When the animal was walking spontaneously (i.e., was not experimentally stimulated), all cells fired some action potentials with variable instantaneous spike frequencies (Table 1; range of mean values: $0.88-168.45 \mathrm{~Hz}$ ). Only two cells (DBNi1-3: Fig. 1; DBNc4-1: Fig. 3) failed to respond to the auditory stimuli tested. As a rule, neurons which responded to the artificial calling song with the conspecific carrier frequency $(5 \mathrm{kHz})$ also responded to the same temporal stimulus pattern with a frequency of $20 \mathrm{kHz}$; however, their response characteristics often differed according to carrier frequency (e.g., DBNc5-4: Fig. 4). Many, but not all neurons also responded to the visual stimulus of a moving grating. Most cells responded with a short burst of action potentials to the "lights off" stimulus with a static grating (e.g., DBNc4-1; cf. DBNc2-1: Staudacher and Schildberger 1998). Only one cell was found that decreased its firing frequency upon "lights off" (DBNi1-3: Fig. 1B). Responses to stimulation by air puffs to the cerci were found in the majority of the cells tested. Cells responded typically with a short burst of action potentials that occurred regardless of whether the animal was walking or not (e.g., DBNi5-1-19: Fig. 5B). Only the i5 neurons showed any correlation between neural activity and translational or rotational velocity of the walking animal in any stimulus situation tested (Pearson's correlation coefficient, criteria: $r>0.5$, $P=0.0002)$. This correlation between the strength of a stimulus response and the rotational velocity of the animal has been reported earlier (Staudacher and Schildberger 1998). In the majority of cells, the responses to the moving grating and the artificial calling song of $5 \mathrm{kHz}$ (both elicit positive taxis behavior) were gated, appearing only during walking. In contrast, responses to air puffs and $20-\mathrm{kHz}$ stimuli (both elicit negative taxis behavior) were not dependent on the walking activity of the animal. Only few cells failed to show such modulations, or showed a different type of response modulation.
No context-dependent modulation of sensory responses: DBNil-3

The soma of this ipsilateral descending neuron (Fig. 1A) is located in the lateral dorsal rind of the protocerebrum. The primary neurite runs medially towards the dorsal medial protocerebrum, where most of the branches are located. From this region, one branch runs in a ventral anterior direction towards the medial ocellus tract. Some arborizations are also found in the dorsal deutocerebrum. This cell is similar to the $\mathrm{O} 3$ neuron (Goodman 1976; Williams 1975) and to an un-named cell reported by Boehm and Schildberger (1992; Fig. 5). Physiological responses may show some differences, but the stimulus programs and parameters used in this study were different too. Therefore, it remains unclear whether this is the same neuron or a sibling with slightly different response characteristics.

The DBNi1-3 cell was the only one recorded which was tonically active even when the animal was standing (Table 1). Furthermore, it was the only cell which did not show any sign of context-dependent gating. During walking, its firing frequency increased significantly (Table 1 ; $t$-test: $P<0.0001)$. When the lights were turned Off, the firing rate of the cell decreased, while turning the lights On resulted in a phasic burst of action potentials (Fig. 1B). Both responses occurred in the walking and the standing animal (Fig. 1B left and right part, respectively), i.e., they were not gated by the walking activity of the animal. When visually stimulated with the grating moving left (ipsilaterally) the walking animal showed a strong turning tendency to the left side, i.e., intended to show optomotor behavior, and changes from light to dark led to short reductions in the activity of the neuron (left part in Fig. 1C). When the animal was standing, the overall activity of DBNil-3 decreased. However, it still responded to the moving grating with short reductions of its activity (right part of Fig. 1C). A comparison of the post-stimulus-time histograms for ipsi- and contralateral movement of the grating shows no obvious principal differences in these responses (Fig. 1D, E).

\section{Modulation over time: DBNc4-2}

The soma of this contralateral descending neuron is located in the ventral pars intercerebralis from where its primary neurite runs posteriorly dorsad (Fig. 2A). Some branches are located in the dorsal protocerebrum. The main arborizations, however, are located in the medial to ventral deutocerebrum. A few branches are also found in the contralateral dorsal deutocerebrum, before the axon descends and runs to the thoracic and then further on into the abdominal ganglia (Fig. 2A).

This is the only neuron showing a time-dependent modulation of one sensory response. The cell responded to the artificial calling song of $5 \mathrm{kHz}$ and $20 \mathrm{kHz}$ if they were presented ipsilaterally (Fig. 2B-E). And only the 


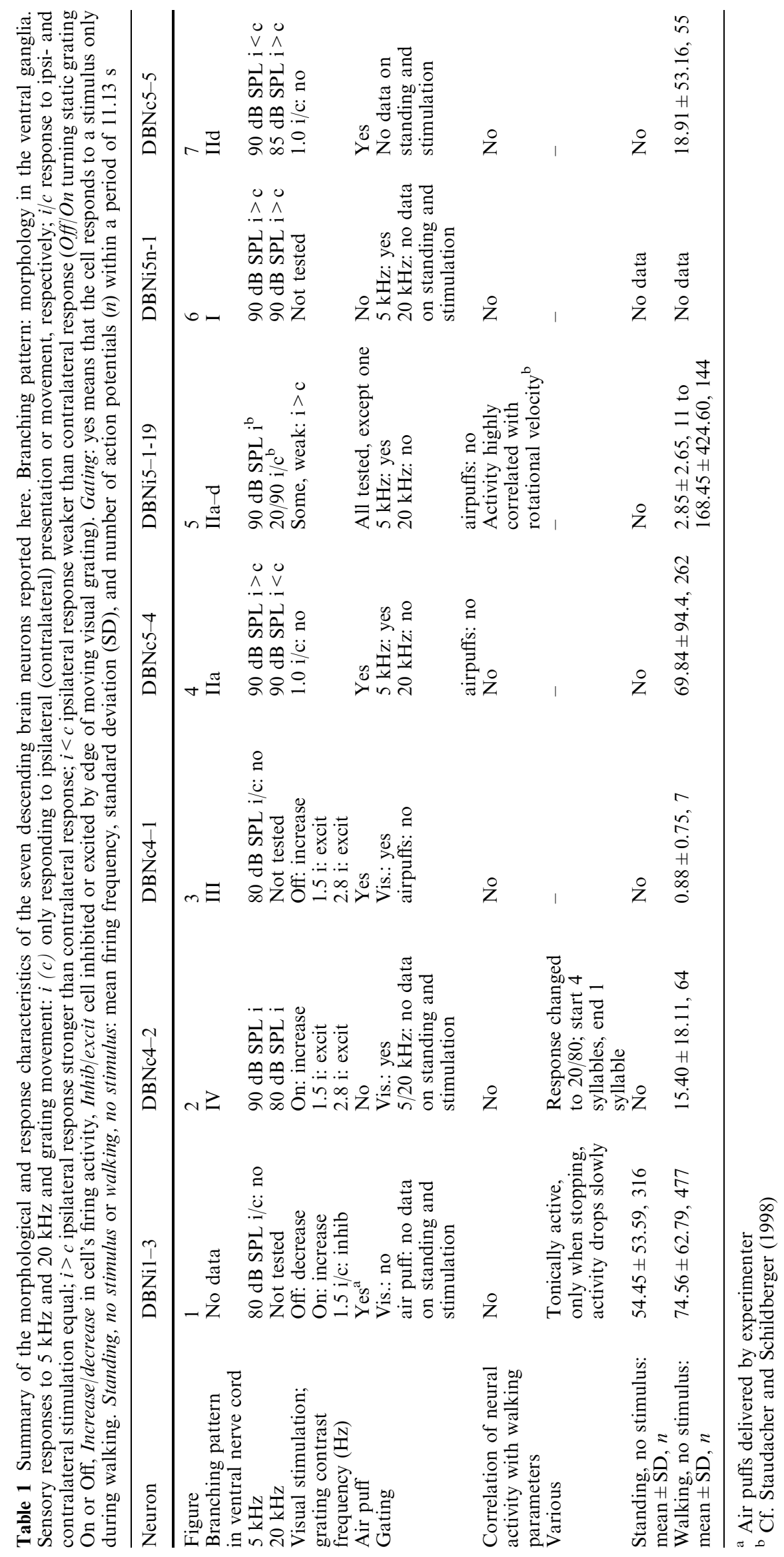



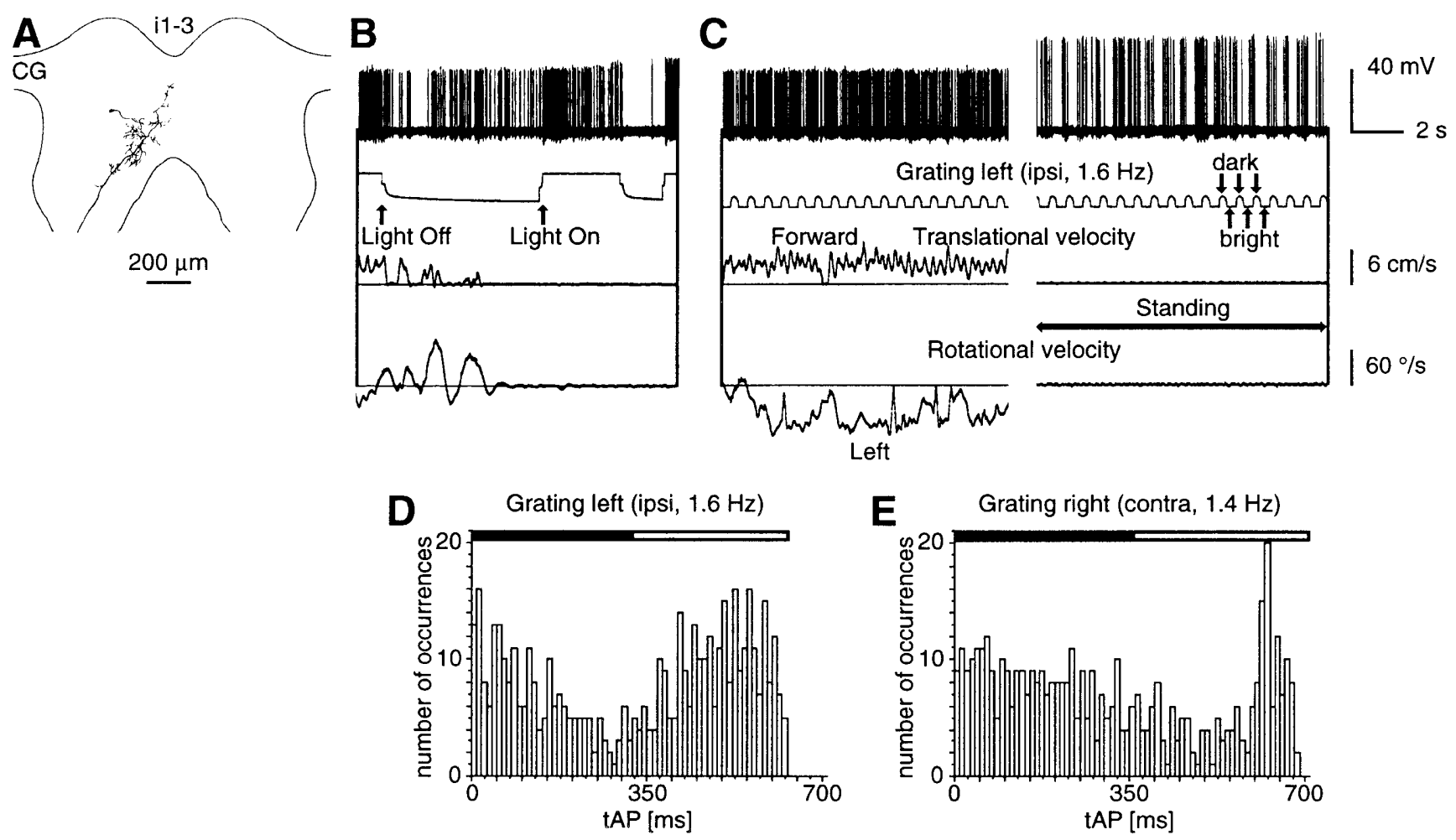

Fig. 1 A Morphology of the ipsilateral descending brain neuron (DBNi)1-3 in the brain; undetermined cell type. B Turning the lights Off decreases and On increases the neural activity. C Stimulation with a grating moving to the left (ipsilateral) side (second trace). In the left part the walking animal shows an optomotor response, i.e., intends to turn left. In the right part the animal is standing. The cell responded with a reduction of its activity to light/dark changes during walking and standing. D Poststimulus-time histogram (PSTH): grating moving left (ipsilateral; contrast frequency: $1.6 \mathrm{~Hz}$ ). The graph illustrates the drop in the activity of the cell to light/dark changes. E PSTH: grating moving right (contralateral; contrast frequency: $1.4 \mathrm{~Hz}$ ). If not stated otherwise, the following conventions are valid for this and all following figures: anatomy - brain morphology was reconstructed from serial vibratome sections $(50 \mu \mathrm{m})$. Morphology in the other ganglia drawn from wholemount photographs. Recording examples: first trace: intracellular recording; other traces: as labeled. PSTH: bin width $10 \mathrm{~ms}$. PSTH and schematized stimulus pattern (dark: off; light: on; or: four syllables) have the same time scale. Unless otherwise stated, the crickets are walking during the time periods represented by the graphs

representation the ultrasound stimulus was modulated over the period of $27 \mathrm{~min}$. At a carrier frequency of $5 \mathrm{kHz}(90 \mathrm{~dB}$ SPL) only the first syllable of each chirp was represented in the response of the neuron (Fig. 2B; mean latency: $31.3 \pm 11.4 \mathrm{~ms}$, mean $\pm \mathrm{SD} ; n=27)$. This did not change within 27 min (cf. Figs. 2B and 2C). In contrast, when the animal was walking, the cell responded to $20 \mathrm{kHz} 80 \mathrm{~dB}$ SPL with a representation of all four syllables (Fig. 2D; mean latency: $32.1 \pm 7.2 \mathrm{~ms}$; $n=62$ ). In the course of time, even in the walking animal, only the first syllable was represented (Fig. 2E: after $27 \mathrm{~min}$ ). In contrast to another cell from the same cluster (see below), DBNc4-2 responded with a short burst of action potentials to turning the lights On. Furthermore, the response to the moving grating was gated by the walking activity of the animal.

Examples for context-dependent gating of categorial responses

In all other descending neurons, representations of stimuli eliciting positive taxis behavior (moving grating, conspecific calling song) were modulated by the walking activity of the animal. In contrast, responses to stimuli approximating predators (air puffs, ultrasound), and thus belonging to a different category, were represented during standing and walking. This means, the cells responded to these stimuli independent of the behavioral context. The following cells shall exemplify these findings and detail variations in response properties with regard to auditory stimuli.

\section{$D B N c 4-1$}

In the brain, this cell is morphologically very similar to DBNc4-2 (cf. Fig. 2A) and in the ventral ganglia it also branches ipsi- and contralaterally (Fig. 3A). Differences in this branching pattern, however, indicate that it is a different cell of cluster $\mathrm{c} 4$, and that it belongs to DBN type III.

In this neuron, responses to the moving grating were gated, while the cell responded to air puffs during walking and standing. The DBNc4-1 cell responded with a short burst of action potentials at light Off. Like 


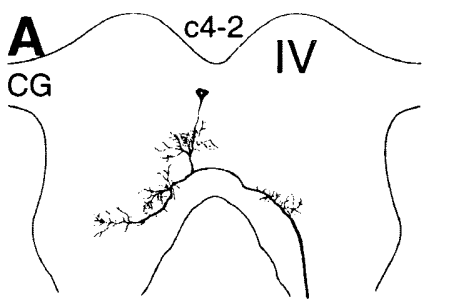

SOG

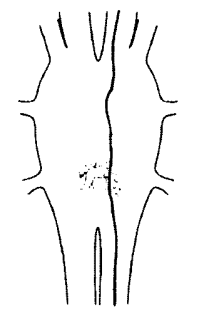

T1

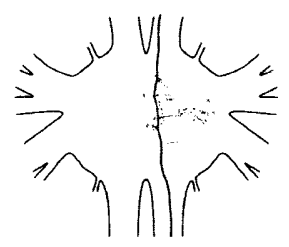

T2

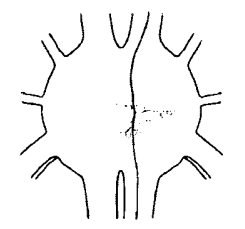

T3

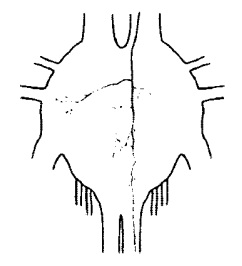

$200 \mu \mathrm{m}$

DBNc4-2, the DBNc4-1 responded to the moving grating. Although the animal showed an optomotor response, the cell only responded to ipsilateral movements of the grating (Fig. 3B; first part). Contralateral movements of the grating were not represented by the cell, even though the animal intended to turn with the grating (Fig. 3B; second part). The response characteristics were not altered at different contrast frequencies of the grating (cf. Fig. 3B, C, and D). Responses to the moving grating clearly depended on the walking activity of the animal, i.e., were gated (Fig. 3E, F). Air puffs elicited short bursts of action potentials (latency: 103.9 \pm $55.2 \mathrm{~ms} ; n=29$ ) and triggered escape runs of the animal (Fig. 3G).

\section{$D B N c 5-4$}

The primary neurite of the DBNc5-4 neuron runs posterior to the medial posterior protocerebrum (Fig. 4A) and has some ipsilateral arborizations there. On the contralateral side, this cell arborizes in the dorsal
Fig. 2 A Morphology of the contralateral descending brain neuron (DBNc)4-2; type IV cell. B, C No time-dependent change in the response to $5 \mathrm{kHz}$. B Beginning of the recording, cell responds to the first syllable of an artificial calling song presented ipsilaterally ( $5 \mathrm{kHz}, 90 \mathrm{~dB}$ SPL). C Response to the same stimulus as in $\mathbf{B}$ remains unchanged even $27 \mathrm{~min}$ later. D, E Time-dependent change in the response to ultrasound. D All four syllables of the ipsilateral stimulus of $20 \mathrm{kHz}, 80 \mathrm{~dB}$ SPL represented. E About 27 min later the cell only responded to the first syllable of the same stimulus. Dot plots: each dot represents the time of occurrence of one action potential $(t A P)$. Dot plots and the schematized stimulus pattern (four syllables) have the same time scale

posterior protocerebrum and the dorsal anterior deutocerebrum.

This example shows striking differences in the context dependence of the conspecific calling song which elicits positive phonotaxis and ultrasound which leads to negative phonotaxis and was not gated. The cell responded only weakly to the contralaterally presented calling song with a carrier frequency of $5 \mathrm{kHz} 90 \mathrm{~dB}$ SPL (Fig. 4B; mean latency: $39.9 \pm 12 \mathrm{~ms} ; n=10)$. However, if the same stimulus was presented ipsilaterally, all four syllables of a chirp were represented by the cell (Fig. 4C; mean latency: $31.3 \pm 11.4 \mathrm{~ms} ; n=15$ ). Moreover, the cell only responded to the artificial calling song with the conspecific carrier frequency while the animal was walking (Fig. 4F). Its response characteristics changed dramatically when the carrier frequency was $20 \mathrm{kHz}$ : all four syllables of the calling song were then represented with good fidelity, but only if the stimulus was presented contralaterally $(20 \mathrm{kHz} 90 \mathrm{~dB}$ SPL; Fig. 4D; mean latency: $30.4 \pm 5.2 \mathrm{~ms} ; n=17$ ). Only the first syllable was represented strongly when the same stimulus was presented from the ipsilateral side (Fig. 4E; mean latency: 


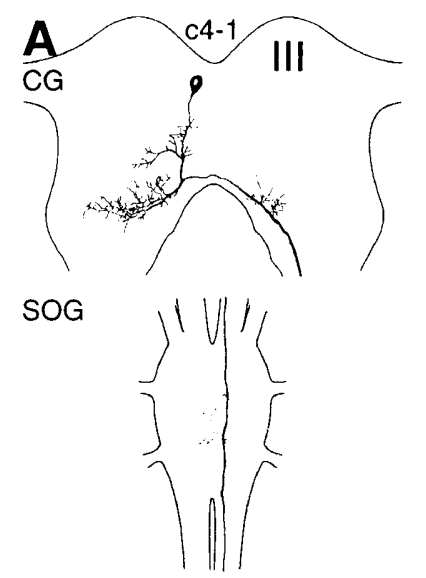

T1

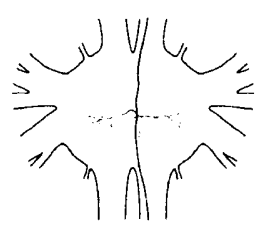

T2

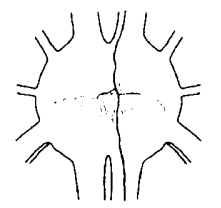

T3

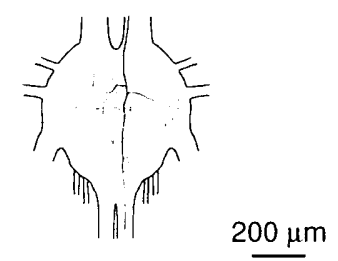

B
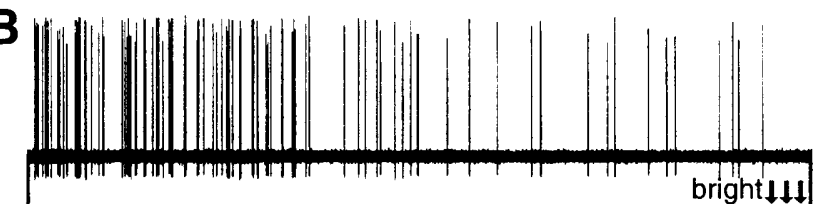

Grating left (ipsi, $2.4 \mathrm{~Hz}$ ) Grating right (contra, $2.2 \mathrm{~Hz}$ ) fft

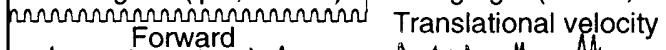

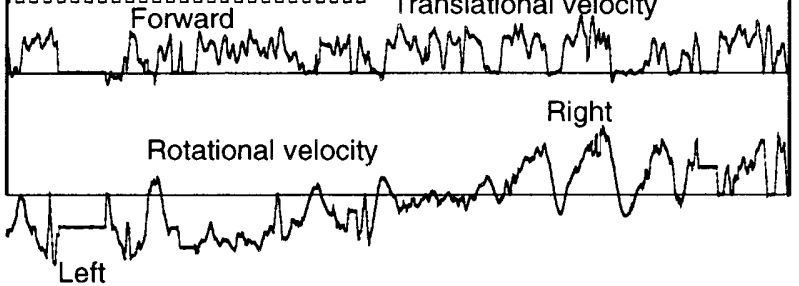

C

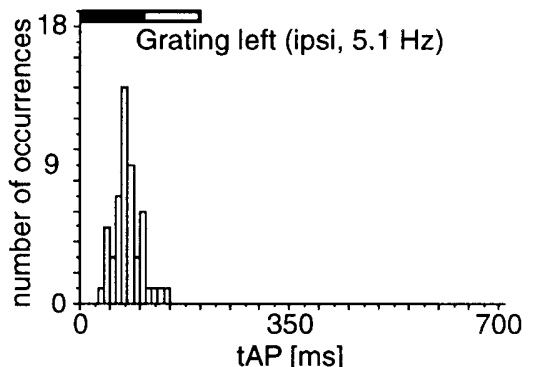

E

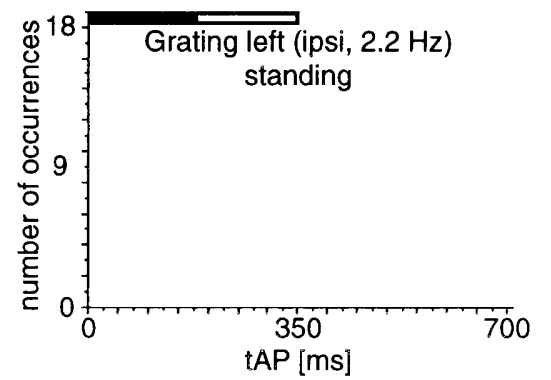

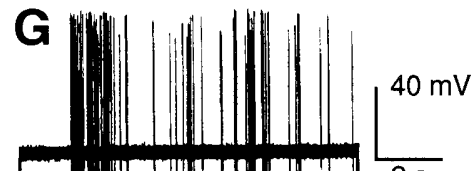

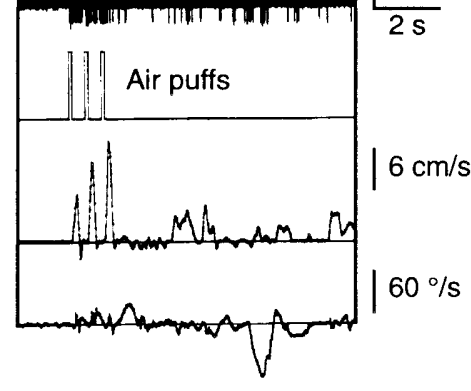

D

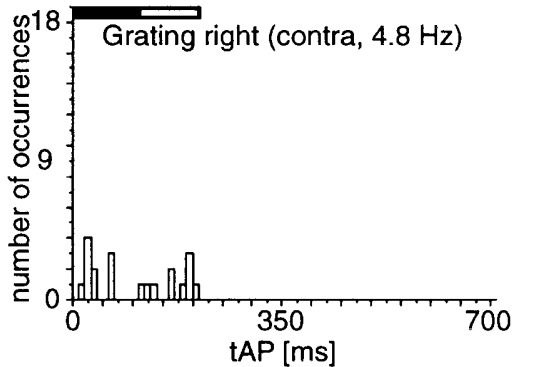

$\mathbf{F}$

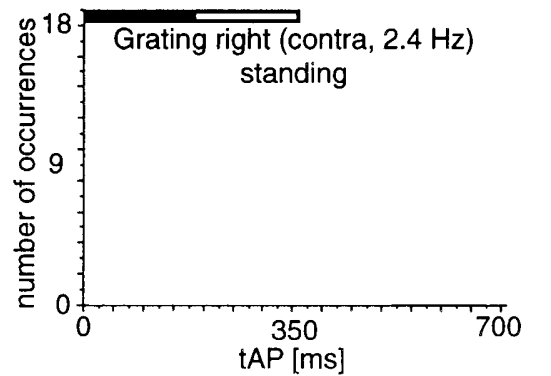

Fig. 3 A Morphology of DBNc4-1; type III cell. B The cell responds to ipsilateral, but not to contralateral grating movement (first and second part, respectively). C The cell's activity is phasically increased by light/dark changes to ipsilateral visual grating movement. D No response to contralateral grating movement. E, F Context dependence: the cell does not represent the moving grating while the animal is standing. $\mathbf{G}$ The neuron responds to air puffs

$32.6 \pm 2.6 \mathrm{~ms} ; n=17)$. Furthermore, responses to the 20 $\mathrm{kHz}$ stimulus were not dependent on the walking activity of the animal (Fig. 4G). Whenever the cerci were stimulated with air puffs, the cell responded with a short burst of action potentials (mean latency: $53.63 \pm$ $22.43 \mathrm{~ms}, n=14)$.

\section{DBNi5-1-19}

The morphology of the cells of the ventral i5 cluster in the brain has been described in detail earlier (Staudacher 1998). All four subtypes are shown in Fig. 5A.

For this group of neurons, context dependent gating could be established for the conspecific calling song.
Like in most other cells described here, ultrasound and air puffs were represented during standing and walking. The cells from cluster i5 only responded to $5-\mathrm{kHz}$ stimuli if the animal was walking and only if they were presented ipsilaterally (range of mean latencies: $33.3 \pm 5.2 \mathrm{~ms} ; n=31$ to $42.5 \pm 6.3 \mathrm{~ms} ; n=7$ ). In contrast, responses to $20-\mathrm{kHz}$ stimuli were not gated and did not depend on the side of the presentation (cf. Staudacher and Schildberger 1998). The mean latencies for ipsilateral stimulation with $20-\mathrm{kHz}$ ultrasound ranged from $29.4 \pm 6.6 \mathrm{~ms} ; n=16$ to $34.5 \pm 7.9 \mathrm{~ms} ; n=15$, and from $24.5 \pm 10.0 \mathrm{~ms} ; n=36$ to $27.7 \pm 3.6 \mathrm{~ms} ; n=33$ for contralateral stimulation. All but one tested DBNi5 cell responded to air puffs delivered to the cerci. Neurons representing this stimulus did so during standing and walking. Stimulation induced phasic increases in the cells' activity, i.e., short bursts of action potentials (Fig. 5B; mean latency: $55.82 \pm 21.18 \mathrm{~ms} ; n=43$ ), and often, but not always, escape runs of the animals were triggered by the air puffs. All DBNi5 cells, which were tested with the moving grating, showed only weak responses during walking. Usually, their activity was higher during ipsilateral movement of the grating than during contralateral stimulation (Fig. 5C). The ipsilat- 

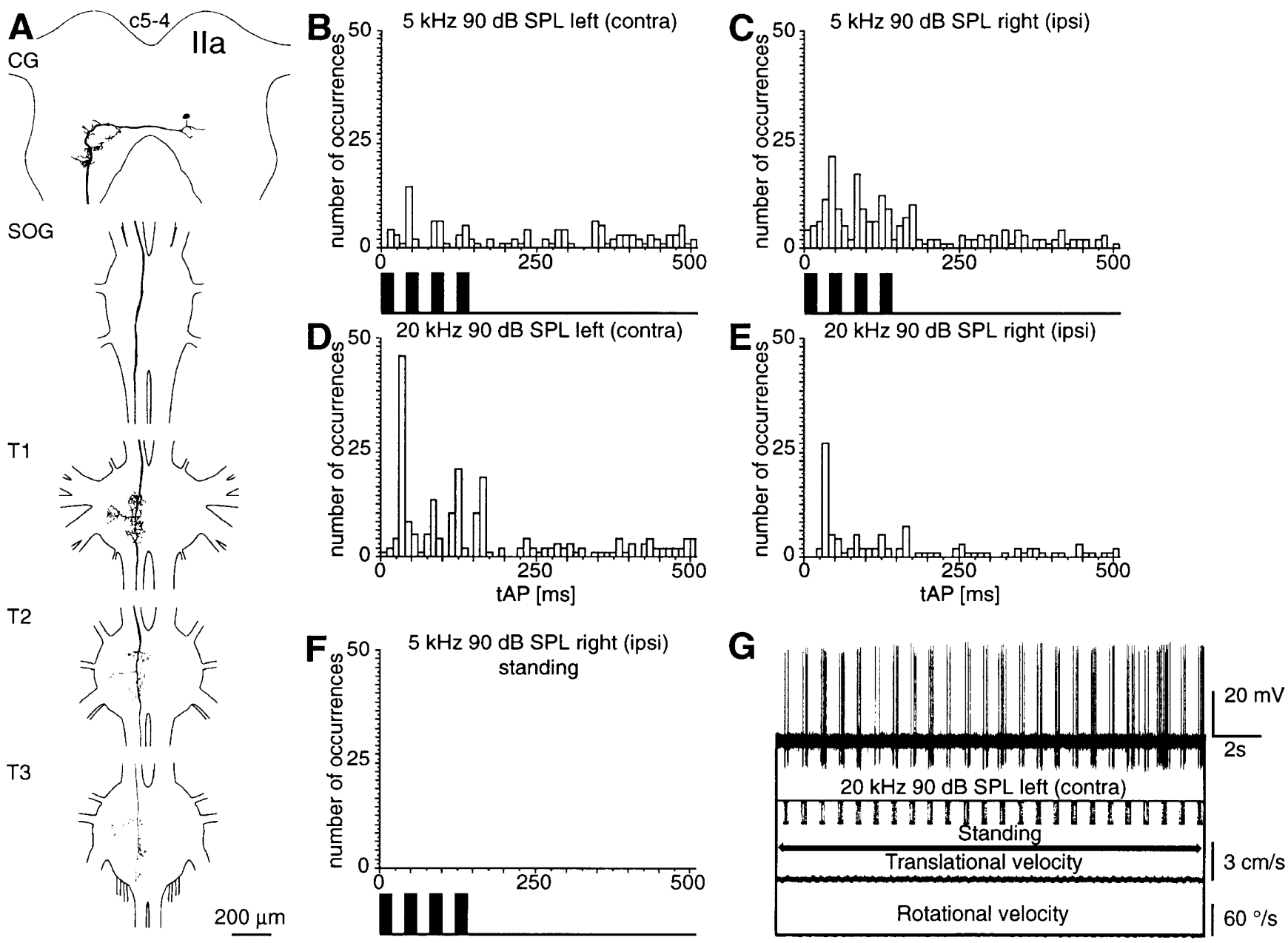

Fig. 4 A Morphology of DBNc5-4; type IIa cell. B Only a weak response to $5 \mathrm{kHz}, 90 \mathrm{~dB}$ SPL left (contralateral). C All four syllables are represented when stimulated with $5 \mathrm{kHz}, 90 \mathrm{~dB}$ SPL right (ipsilateral). D Mirror image response to ultrasound. All four syllables are represented at $20 \mathrm{kHz} 90 \mathrm{~dB}$ SPL left (contralateral). E Mirror image response to ultrasound. Weaker response to $20 \mathrm{kHz}$ $90 \mathrm{~dB}$ SPL right (ipsilateral). F and $\mathbf{G}$ Context dependence of categorial responses. While standing, $\mathbf{F}$ no response to right (ipsilateral) presentation of $5 \mathrm{kHz}, 90 \mathrm{~dB}$ SPL, but $\mathbf{G}$ ultrasound stimulus is represented

eral movement was represented by a phasic increase of the neuron's activity (Fig. 5D). During contralateral movement of the grating, the response was weaker or no response was found (Fig. 5E). However, more data are needed to gain a clear-cut picture of the different responses of the i5 cells to visual stimuli.

\section{DBNi5n-1}

The perikaryon of this neuron is located in a small ventral medial cluster (Fig. 6A). By making a laterodorsal curve between the peduncle and the $\alpha$-lob the primary neurite runs to the dorsal protocerebrum. The main arborization zone of the cell is located dorsally, posteriorly and laterally to the central complex. In the protocerebrum, a prominent median collateral branches off and runs parallel to the axon. The arborizations given off from this collateral and the axon are located ipsilaterally in the dorsal proto- and deutocerebrum.

Like many others, DBNi5n-1 responded to $5 \mathrm{kHz}$ only during walking. The post-stimulus-time histograms (PSTHs) show that DBNi5n-1 responded strongly to both, the ipsilaterally presented artificial calling song with the conspecific carrier frequency and ultrasound (Fig. 6B-F). When a stimulus of $5 \mathrm{kHz} 90 \mathrm{~dB}$ SPL was presented ipsilaterally all four syllables were represented by the cell (mean latency: $46.9 \pm 16.7 \mathrm{~m} ; n=45$; Fig. $6 \mathrm{~B}$, D). However, only the first syllable was represented during contralateral stimulation (mean latency: $36.1 \pm 4.4 \mathrm{~ms} ; n=16$; Fig. $6 \mathrm{~B}$; middle part and Fig. $6 \mathrm{C}$ ). When stimulated with $20 \mathrm{kHz} 90 \mathrm{~dB}$ SPL from the ipsilateral side, single syllables were represented only weakly, while the whole chirp was represented strongly

Fig. 5 A Morphology of all four subtypes $(I I a-d)$ of the DBNi5 cluster. B These cells respond to air puffs during standing and walking. C The neuron shows higher activity during ipsilateral than during contralateral visual grating movements (first and second part, respectively). D During ipsilateral grating movement, the cell's activity increases phasically with light/dark changes. E No response to contralateral grating movement 
(mean latency: $34.4 \pm 11.6 \mathrm{~ms} ; \mathrm{n}=27$; Fig. 6F). The cell side (mean latency: $37.0 \pm 7.5 \mathrm{~ms} ; \mathrm{n}=11$; Fig. 6E). responded only very weakly when the animal was stim- This was one of the few cells that did not respond to ulated with $20 \mathrm{kHz} 90 \mathrm{~dB}$ SPL from the contralateral stimulation of the cerci with air puffs.

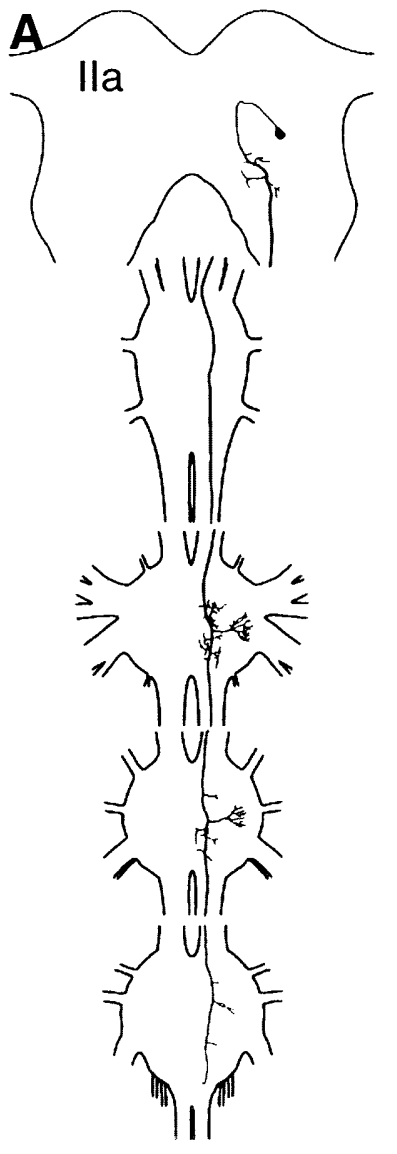

B

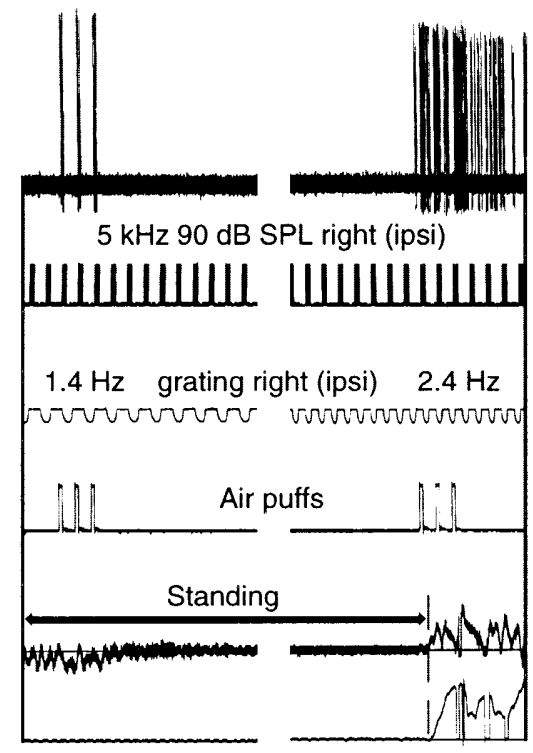

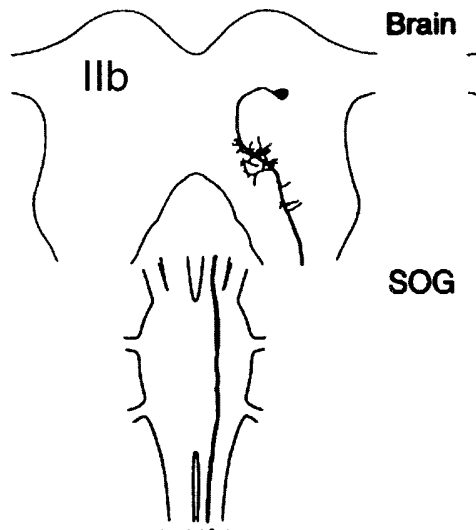
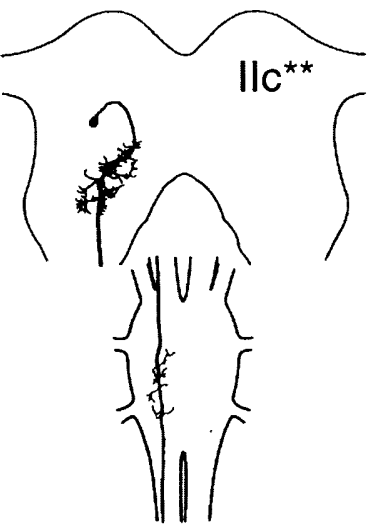

T1
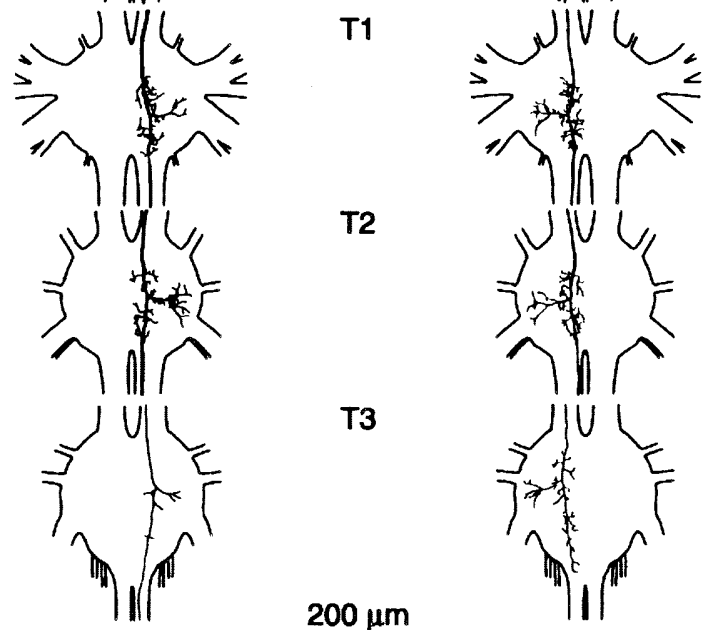

T2
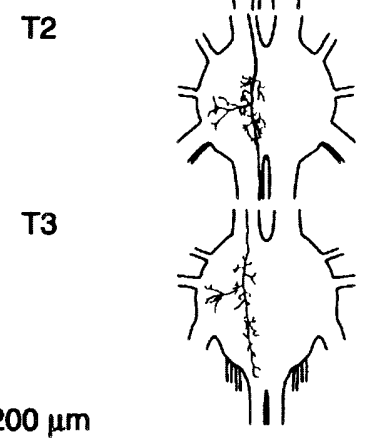

C
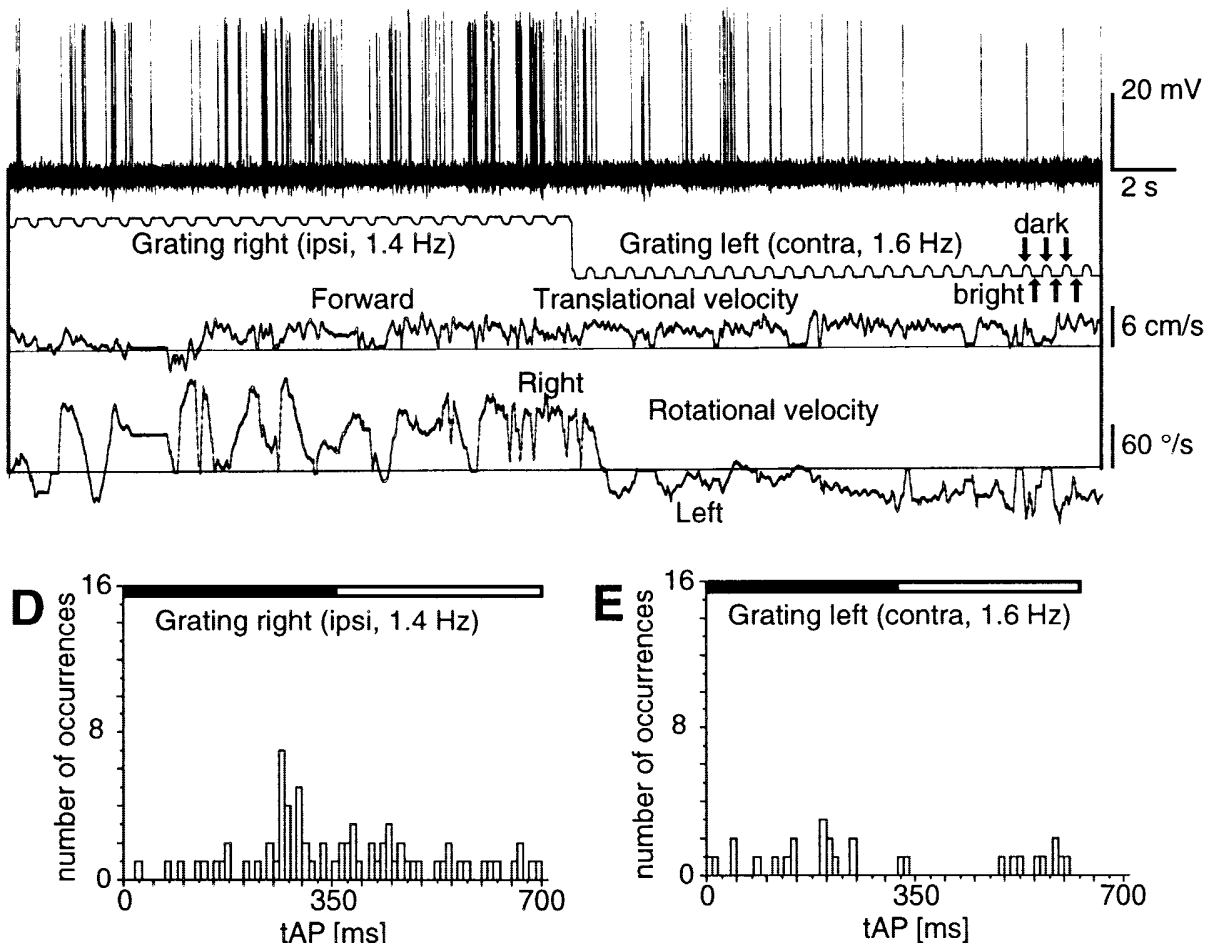


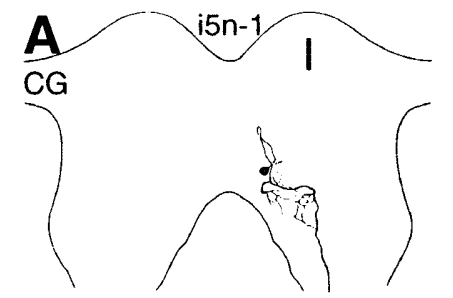

SOG

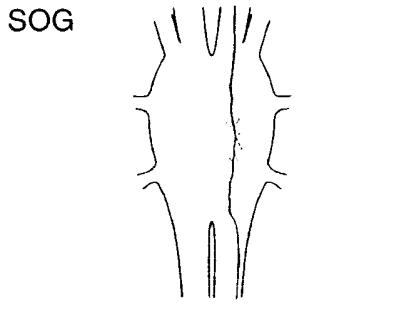

T1

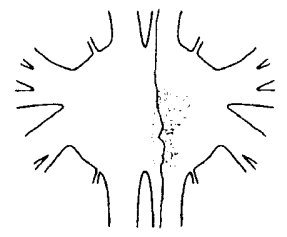

T2

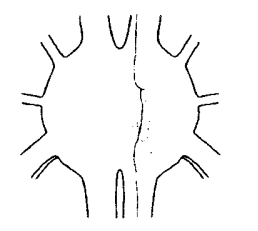

$200 \mu \mathrm{m}$
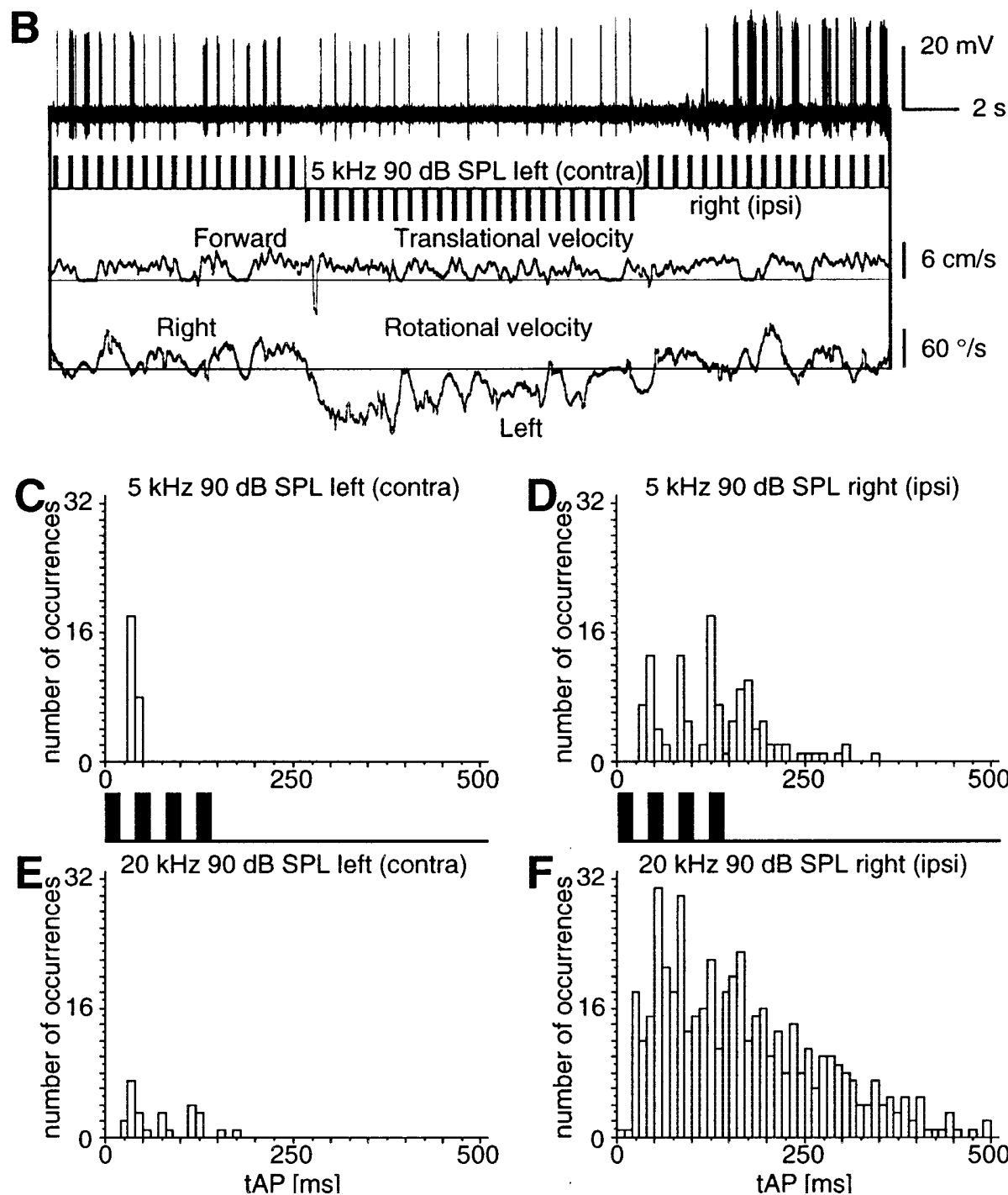

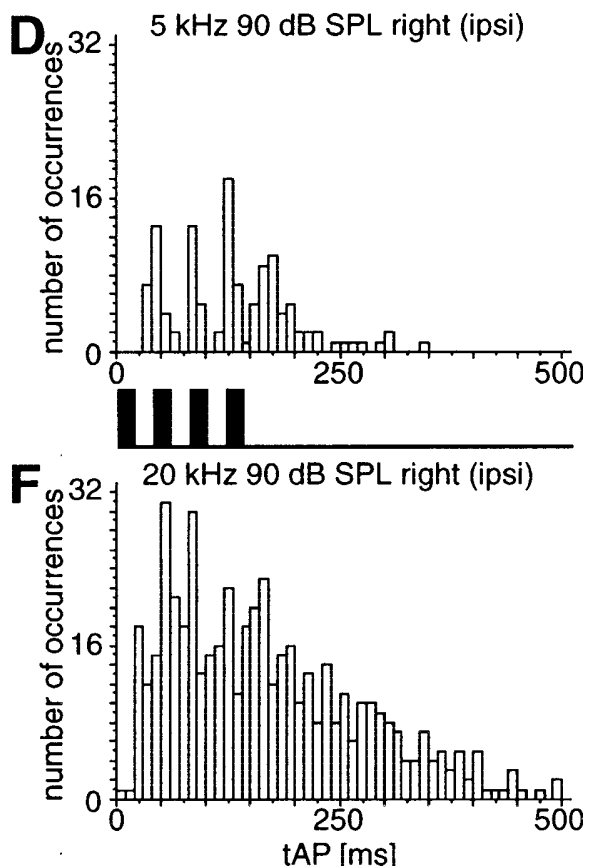

Fig. 6 A Morphology of DBNi5n-1; type I cell. B The cell responds to ipsi- ( first and last part) and contralateral (middle part) stimulation with $5 \mathrm{kHz}, 90 \mathrm{~dB}$ SPL. C It only represents the first syllable during contralateral stimulation. D All four syllables are represented during ipsilateral stimulation. E Only a weak response to $20 \mathrm{kHz}, 90 \mathrm{~dB}$ SPL left (contralateral). F The whole chirp is represented during ipsilateral (right) presentation of $20 \mathrm{kHz}, 90 \mathrm{~dB}$ SPL

\section{$D B N c 5-5$}

The ipsilateral arborizations of this neuron from the ventral cluster c5 (cf. DBNc5-4, Fig. 4) are located dorsal to the central complex in the diffuse neuropile of the posterior lateral protocerebrum (Fig. 7A). Its axon descends contralaterally without further branching.

The animal walked throughout the experiment. Therefore, no statement can be made about walkingdependent gating of the sensory responses of this cell. However, the auditory response characteristics of this cell were reversed in a manner suggesting mirror sym- metry with regard to DBNc5-4 (cf. Fig. 4B to Fig. 7C, Fig. 4C to Fig. 7D, Fig. 4D to Fig. 7E, and Fig. 4E to Fig. 7F). During walking, the cell responded to all four syllables of an artificial calling song of $5 \mathrm{kHz} 90 \mathrm{~dB}$ SPL only when it was presented contralaterally (Fig. 7C; mean latency: $24.5 \pm 1.0 \mathrm{~ms}, n=36$ ). The recording presented (Fig. 7B; first and last parts) shows that this response was not dependent on the walking direction of the animal. An ipsilateral presentation of the same stimulus only led to a weak response (Fig. 7D; mean latency: $46.0 \pm 11.5 \mathrm{~ms}, n=28)$, even though the animal itself was showing phonotactic behavior (Fig. 7B; middle part). The PSTHs show that the response properties of the cell were different for stimulation with $20 \mathrm{kHz}$ (Fig. 7E, F). Here, the response to a stimulus of $20 \mathrm{kHz}$ $85 \mathrm{~dB}$ SPL was represented more strongly when presented ipsilaterally (mean latency: $34.5 \pm 10.5 \mathrm{~ms}$, $n=22$ ), while there was no response to contralateral stimulation. When air puffs were delivered to the cerci, the cell responded with a few action potentials (mean latency: $69.07 \pm 26.85 \mathrm{~ms}, n=9$ ). 


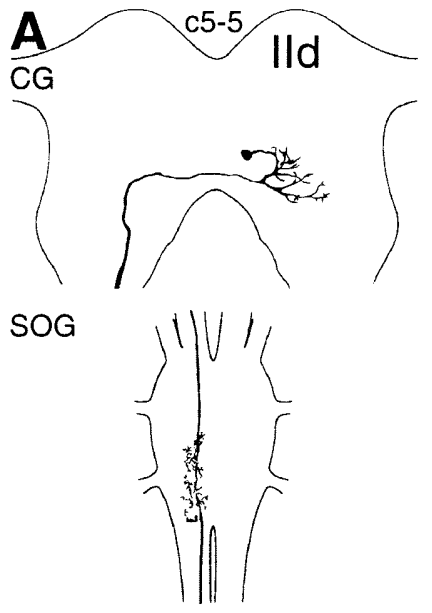

T1

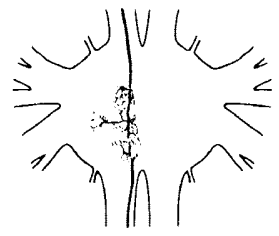

T2

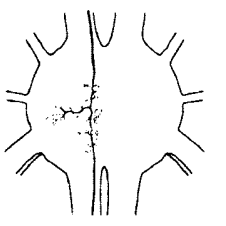

T3

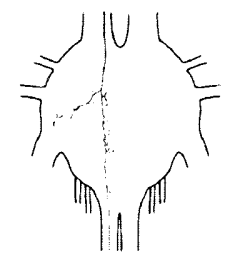

$200 \mu \mathrm{m}$
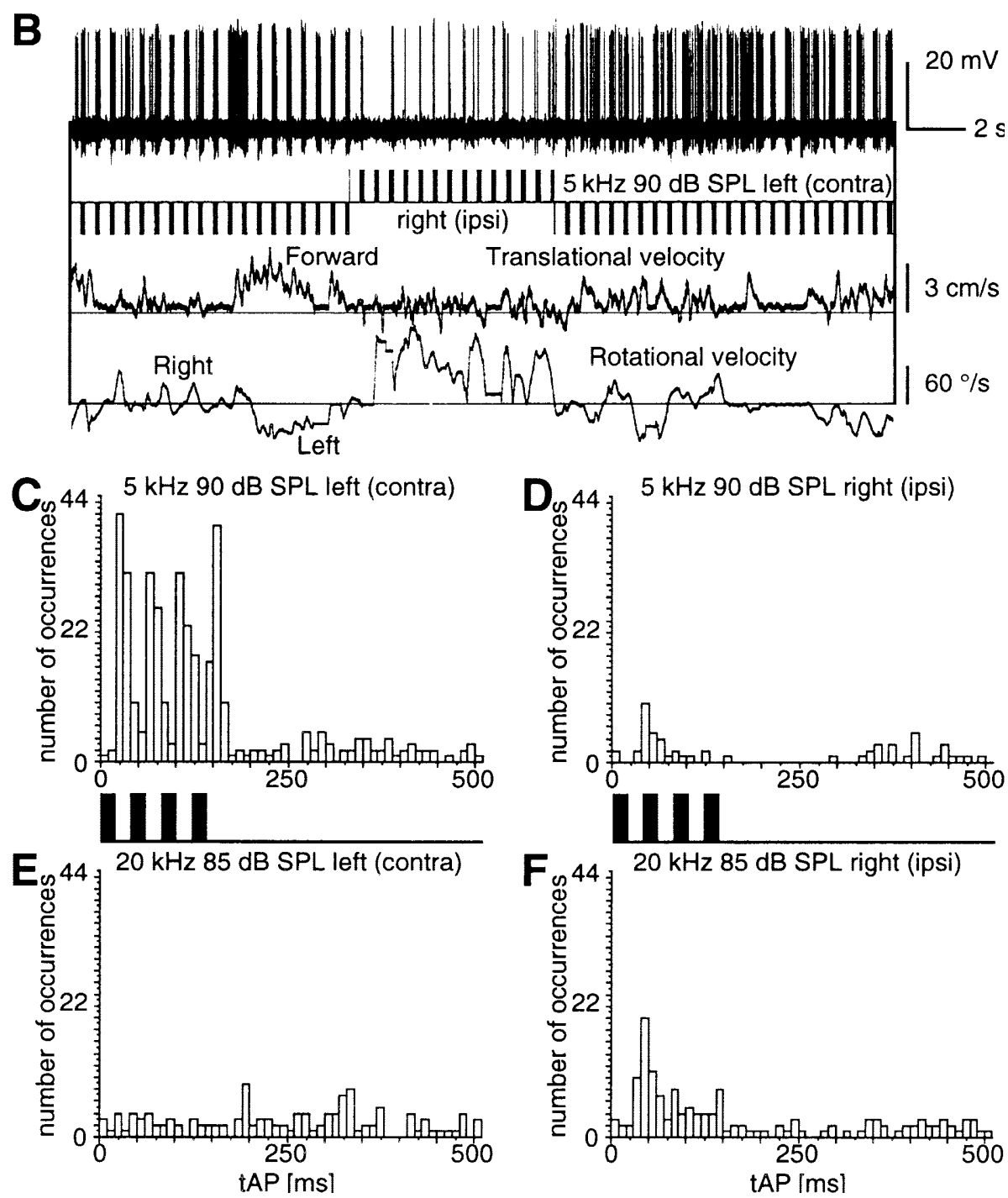

Fig. 7 A Morphology of DBNc5-5; type IId cell. B-F The response characteristics of this cell seem to be reversed with respect to DBNc5-4 (cf. Fig. 4B-E). B The cell responds the ipsi- (middle part) and contralateral (first and last part) stimulation with $5 \mathrm{kHz}$, $90 \mathrm{~dB}$ SPL. C All four syllables are represented during contralateral stimulation. D It only represents the first syllable during ipsilateral stimulation. E Mirror image response to ultrasound. No response at $20 \mathrm{kHz}, 85 \mathrm{~dB}$ SPL left (contralateral). F Mirror image response to ultrasound. Stronger response to $20 \mathrm{kHz}, 85 \mathrm{~dB}$ SPL right (ipsilateral)

\section{Discussion}

Sensory responses and brain morphology

The anatomy and physiology of a number of descending brain neurons has been described in several insects (e.g., Bacon and Moehl 1983; Boehm and Schildberger 1992; Boyan and Williams 1981; Brodfuehrer and Hoy 1990; Gebhardt and Honegger 1997; Griss and Rowell 1986; Gronenberg and Strausfeld 1991; Hedwig 1994; Hensler 1988; Hoerner and Gras 1985; Homberg 1994b; Horseman et al. 1997; Kanzaki et al. 1991; Olberg 1986;
Richard et al. 1985; Rind 1990; Rosentreter and Schuermann 1982; Rowell and Reichert 1986; Staudacher and Schildberger 1998; Williams 1975; Ye and Comer 1996). The different cells shown here have partly overlapping sensory response characteristics, thus resembling parallel descending pathways. Nevertheless, the cells can be divided into two groups based on a combination of brain morphology and response characteristics. Group I neurons strongly responding to visual stimuli have their branches in the dorsal medial protocerebrum, or even send branches into ocellar tracts (cf. Staudacher and Schildberger 1998). Their responses to air puffs may be mediated by branches in the posterior dorsal protocerebrum, where the giant ascending cercal interneurons terminate (Boyan et al. 1989). Most cells of the group II also responded to air puff stimulation and have branches in the same area. Group II, and the majority of descending brain neurons shown here responded to an artificial calling song of $5 \mathrm{kHz}$ and $20 \mathrm{kHz}$, but their responses to these frequencies often differed strongly. Moreover, their response properties were also very different from responses of the auditory receptors and 
primary interneurons recorded under similar "free-field" conditions (Boyd and Lewis 1983; Horseman and Huber 1994a, 1994b; Stabel et al. 1989). Compared to latencies known from ascending primary interneurons, the latencies of the auditory responses of descending neurons are relatively long. They range from $25 \mathrm{~ms}$ to $47 \mathrm{~ms}$ for $5 \mathrm{kHz}$ and $24 \mathrm{~ms}$ to $35 \mathrm{~ms}$ for $20 \mathrm{kHz}$ (cf. Brodfuehrer and Hoy 1990; Schildberger 1984b). These long latencies indicate that some preprocessing might take place before the descending cells are activated. Local brain neurons are candidates for this and the ipsi- and contralateral connections. Some such cells have been described previously, and some even have branches in the dorsal posterior protocerebrum where many descending neurons have large arborization zones (Boyan 1980; Brodfuehrer and Hoy 1990; Schildberger 1984b; this study). It therefore seems to be of general importance for understanding the responses of descending brain neurons and their significance to elucidate their connections in the dorsal protocerebrum.

In insects, descending cells only represent about $0.3-$ $1.5 \%$ of the brain neurons, which illustrates the large degree of convergence of other neurons onto them (Staudacher 1998). Therefore, it is not surprising that most descending neurons respond to more than one type of stimulus (e.g., Boehm and Schildberger 1992; Brodfuehrer and Hoy 1990; Gronenberg et al. 1995; Hensler 1992b; Hoerner 1992; Kanzaki et al. 1991; Rowell and Reichert 1986; Strausfeld et al. 1984; this study). In the cells presented here, stimulation with a combination of stimuli often led to increased firing activity. It has previously been reported that stimuli which separately led to only weak responses led to stronger responses when they are combined, or that their responses added up arithmetically when combined (Boehm and Schildberger 1992; Hensler 1988; Milde and Strausfeld 1990; Olberg and Willis 1990; Reichert and Rowell 1986). Such properties are referred to as situation- or context-dependent responses rather than multimodal responses (Reichert and Rowell 1986). Situation-dependent responses might be regarded as a basis for behavioral changes which occurred when different stimuli were combined (Boehm et al. 1991; Weber et al. 1987), although behavioral changes may also result from simultaneous alterations in the activity of parallel pathways responding to different modalities.

\section{Connections to the ventral nerve cord}

This report, and other studies, show brain and ventral ganglion morphology and physiological properties of insect descending brain neurons (e.g., Burdohan and Comer 1996; Griss and Rowell 1986; Hedwig 1986, 1994; Hensler 1988; Olberg 1986; Olberg and Pinter 1990; Olberg and Willis 1990; Richard et al. 1985; Rind 1983a, 1990; Simmons 1980b; Staudacher and Schildberger 1998; Strausfeld et al. 1984). The information for the DBNi5 cluster (Fig. 5) presented here shows that it might not always be sufficient to describe input regions and sensory responses for identifying neurons individually: (1) the 19 is cells are morphologically very similar in the brain (Staudacher 1998), and (2) their response properties are very similar (Staudacher and Schildberger 1998; this account). However, data presented here show consistent variations of the arborization patterns of descending brain neurons in the suboesophageal ganglion, in the thoracic ganglia, and in their connections to the abdominal ganglia, which defines different types and subtypes.

The arborizations of descending brain neurons are usually located in the dorsal to medial areas of the ventral ganglia (e.g., Hoerner 1992; Richard et al. 1985; Staudacher and Schildberger 1998; this study). Connections from descending cells to cells in the suboesophageal ganglion may be important in both walking and flight and for changing metabolism and breathing pattern according to ongoing behavior (Kien 1983; Ramirez 1988, 1998). The dorsal to medial location of their branches in the thoracic ganglia suggests connections to flight motor neurons and bimodal flight/walking motor neurons (Pflueger et al. 1986; Ramirez and Pearson 1988). Only in a couple of cases have direct connections of descending brain neurons with flight motor neurons been shown. In these examples, fast reactions seem to be necessary in order to successfully stabilize flight (locusts: Hensler and Rowell 1990; Reichert and Rowell 1985; Simmons 1980a; moths: Rind 1983a, 1983b) or pursue a small, fast moving target (flies: Gronenberg and Strausfeld 1991). Direct connections to bifunctional motor neurons and to flight and leg motor neurons have been described for descending cells involved in initiating escape reactions resulting in flight (locusts: Burrows and Rowell 1973; Simmons 1980b; flies: Milde and Strausfeld 1986, 1990; Trimarchi and Schneiderman 1995a, 1995b, 1995c). Although many descending brain neurons have collaterals to the root of the large leg nerve N5 in the thoracic ganglia, direct connections to neurons intimately involved with walking and their significance remain to be shown for most of them. It seems likely, however, that the majority of descending neurons connect at least to premotor interneurons, like non-spiking cells which have been shown to be important for appropriately configuring the thoracic circuits for different motor tasks (Driesang and Bueschges 1996). Furthermore, many descending neurons run into and arborize in the abdominal ganglia (E.M. Staudacher, unpublished observation). Although the significance of their abdominal branches is not yet known, it is conceivable that they play a role during various behaviors. In insect flight, for example, movements of the abdomen contribute to steering and stabilization (Baader 1990, 1991; Moiseff et al. 1978; Pollack and Hoy 1981) just as do leg movements (Arbas 1986; May and Hoy 1990; Miles et al. 1992). Generally, it seems that indirect connections could be of major importance for behavioral choice, while fast, direct connections might primarily serve to modify ongoing behavior or mediate startle responses. In addition, 
connections to cells in the suboesophageal ganglion and abdominal ganglia may help to tune the whole animal to the chosen behavior.

Neurotransmitters and function of descending brain neurons

What we now know about two type II neurons of the same cluster, DBNc5-4 and DBNc5-5 (Figs. 4 and 7, respectively), exemplifies the need for data on the immunocytochemistry of descending cells. Both neurons respond to the artificial calling song with the conspecific and ultrasound carrier frequency. However, their directional characteristics seem to be reversed. One can imagine that either cell could be involved separately in eliciting positive or negative phonotaxis. However, because of the mirror symmetry of their response characteristics, and because their branches reach into the same regions, it is currently difficult to imagine how their simultaneous activity might be integrated to produce positive and negative phonotaxis. One might speculate that they can contribute to organized phonotaxis only if they either connect to opposing neural elements in the thorax, use different transmitters, or both. From other systems, it also becomes increasingly clear that neuromodulation may play an important role for the configuration of the motor circuits (cf. Driesang and Bueschges 1996), appropriately fine-tuning the behavior of the animal or switching to another behavior (Harris-Warrick et al. 1997; Kupferman et al. 1997). It is, therefore, clear that a combined view of morphology, immunocytochemistry (Homberg 1994a; Wendt and Homberg 1992), and physiology would be of general value to functionally interpret data on descending brain neurons.

\section{Descending activity and behavior}

Clear examples of descending brain neurons being more or less crucial for specific behaviors are very rare for any animals. The Mauthner cell in the medulla oblongata of fishes, elicits a so-called "C-start", a fast escape reaction (Eaton and Bombardieri 1978). Later, it was shown that another pathway exists which elicits a very similar reaction with a slightly longer latency (Eaton et al. 1982, 1984). Therefore, in a strict view, the Mauthner cell does not fulfill the criteria of sufficiency and necessity (Kupfermann and Weiss 1978). Systematic manipulations of the activity of cricket descending brain neurons during standing and walking led to the characterization of one descending neuron necessary and sufficient to initiate and sustain walking activity (Boehm and Schildberger 1992). In both grasshoppers and crickets, Hedwig (1994, 1996) identified command-like neurons necessary and sufficient for singing. However, at least in grasshoppers, the whole behavioral sequence seems to be controlled by the sequential activity of a set of neurons, not just by a single command cell (Hedwig and Heinrich 1997).
Highly significant correlations of neural activity and behavioral parameters are commonly accepted as evidence that the activity of a given neuron could be relevant for a specific behavior. Such correlations could not be established for the cells described here, except for the i5-cells (cf. Staudacher and Schildberger 1998).

However, many of the descending neurons in other studies, and many described here have partly overlapping stimulus/response characteristics, and thus probably represent parallel descending pathways (e.g., Boehm and Schildberger 1992; Hensler 1992b; Kanzaki et al. 1991; Olberg 1986). Moreover, differences in their arborization patterns indicate that some of the descending brain cells may connect with the same, yet others with different, neural circuits in the ventral nerve cord. Differences in their transmitters would further define their impact on the local networks controlling motor behavior. This suggests similarities regarding how motor tasks are represented in the vertebrate nervous system. For example, the weighted activity vector of a population of cells in the motor cortex, each cell of which is not very precise and has slight differences in its tuning, leads to a more precise representation of reaching movements (Georgopoulos 1991, 1996; Georgopoulos et al. 1986). Walking behavior of cats and swimming in lampreys also seems to depend on the context-dependent activity of parallel descending pathways (Deliagina et al. 2000; Grillner 1975; Grillner and Wallén 1984; Grillner et al. 1991). Similarly, it has been proposed that the distributed activity in parallel pathways codes for insect behavior (Kien 1983; Rowell 1993), suggesting a comparison with "across-fiber" patterns like that reported for vertebrate gustation (Erickson 1963; Pfaffmann 1955). Sparks et al. (1997) agree that decision-making in invertebrates and vertebrates probably is based mostly on the "consensus" of many neurons.

State-dependent changes of the impact of neural key elements may be of additional importance in understanding how a heterogeneous group of neurons could contribute to the production of a variety of specific behaviors. Such context-dependencies have been described before. Air puffs to the cerci of a walking cockroach elicit escape runs, but initiate flying in the same animals if they have lost tarsal contact with the ground (Ritzmann et al. 1980). An ultrasound avoidance reaction to bat-like sounds only occurs in flying crickets, although the ascending auditory key element, Int 1 , is activated in the same way in the non-flying and flying animal (Nolen and Hoy 1984). Recently, Hedwig (2000) described a similar phenomenon in a command-like interneuron for singing in crickets, which failed to elicit singing when the cerci of the animal were stimulated with air puffs. Three known mechanisms might be important in this context, all of which have been reported for descending brain neurons. The integration of the often patterned activity of descending cells in the ventral nerve cord depends on context-dependent gating in thoracic motor centers (Griss and Rowell 1986; Madsen and Miller 1987; Nolen and Hoy 1984; Reichert and Rowell 1985, 1986; 
Ritzmann et al. 1980; Rowell and Pearson 1983). It has further been shown in different systems that descending activity will only influence the activity of the motor centers given appropriate timing of the descending signals (Grillner et al. 1991; Reichert and Rowell 1986). This may play a role in the context-dependent sufficiency of the command-like interneuron for singing in crickets (Hedwig, 2000). Findings for another descending neuron, DBNc2-1, hint in a similar direction (Staudacher and Schildberger 1998). During walking, the activity of this cell is not correlated with the turning behavior of the animal, but it can influence turning during flight (Hensler 1992a). Another mechanism may be that sensory responses of descending neurons themselves depend on the motor activity of the animal, i.e., context-dependent gating of categorial responses occurs centrally. Like many other descending cells described here, DBNi5 neurons respond to the auditory stimulus of $5-\mathrm{kHz}$ artificial calling songs when the animal is walking, but not during standing (cf. Staudacher and Schildberger 1998). Furthermore, some DBNi5 cells seem not to respond to this stimulus when the animal is flying (DBIN2; Brodfuehrer and Hoy 1990). This could mean at least one of two things: (1) DBNi5 cells don't respond to the conspecific calling signal during flight (but we know that crickets do respond in flight), or (2) their response depends on the correctness of the temporal pattern of the stimulus. The latter possibility would indicate that the response of $\mathrm{DBNi} 5$ neurons depends on song recognition and, therefore, that DBNi5 cells are connected with the output of the recognition network in the brain. We have no independent demonstration of such a connection. In contrast, i5 cells and most descending brain neurons described here responded to ultrasound stimuli or air puffs to the cerci, both used to mimic predators, in both standing and in walking animals. Thus, the differences in the responses to potentially dangerous versus attractive or other stimuli might reflect a categorization of stimuli in the descending pathway, which might be based on relatively simple stimulus parameters (Hoy 1989; Layne et al. 1997). It does not seem surprising that nearly all the descending neurons responded to air puffs or that nearly all the auditory descending cells responded to ultrasound. Due to the large number of responding cells, which also respond during other behavioral contexts, the escape response thus might be triggered faster and more reliably. Context-dependent gating might turn off the transmission of responses to stimuli of some categories during particular behaviors like standing, maybe also during feeding or post-copulatory guarding, and thus may prevent untimely behavioral reactions. On the other hand, it could allow information transfer about stimuli of a predator category during many behavioral contexts, thus always enabling escape reactions. Operational tests with stimuli of different categories during different behavioral contexts (walking, flying; cf. Ramirez and Pearson 1988) should help to elucidate the notion of distributed activity of such neurons and their state-dependent changes.
The emerging picture about how descending neurons are involved in determining insect behavior may be as follows. An alteration in the stimulus situation might change the pattern of activity in a population of parallel descending neurons. Context-dependent gating might induce further changes in this "across-fiber" pattern. Furthermore, the current behavioral state might determine whether or not the activity of a particular descending cell is gated to local circuits. Thus, various local circuits in the ventral ganglia might be excited/ inhibited in altered ways. The resulting changes in their configurations and balance could finally define the behavioral reaction actually taken in the given situation. Consequently, a command-like neuron could be a cell with a very high influence on certain aspects of the behavior in only special contexts, determined by the internal state of the animal, the preceding and ongoing behavior, and the particular external stimuli. Under different circumstances, the influence of the same cell might be reduced or canceled, like in the descending brain neuron for singing in crickets (Hedwig 2000, Fig. 8). This could also explain how a single cell might be involved in producing different behaviors (Xin et al. 1996). The results presented here suggest that this may be the case for many of the descending brain cells, in particular for cells, which respond to the calling song and ultrasound and therefore are active during both positive and negative phonotaxis.

However, many more anatomical and physiological experiments, some of which are indicated above, are necessary to fully understand the role of descending brain neurons and how this relatively small population of cells contributes to the rich set of behaviors in insects.

Acknowledgements I am grateful for the generous support I received from Prof. Dr. F. Huber (Seewiesen) and Prof. Dr. K. Schildberger (Seewiesen/Leipzig) during the time in Seewiesen, where the experiments were done. I thank Prof. T. Moore for comments on the manuscript and correcting the English. F. Antoni (Seewiesen), P. Heinecke (Seewiesen) and J. Sagunsky (Seewiesen) developed the mechanical and electronic apparatus. S. Schmaderer (Seewiesen) introduced the author to various techniques. The MaxPlanck Society granted a graduate student stipend. The experiments comply with the "Principles of animal care", publication No. 86-23, revised 1985, of the National Institute of Health and also with the laws of Germany (Tierschutzgesetz).

\section{References}

Arbas EA (1986) Control of hindlimb posture by wind-sensitive hairs and antennae during locust flight. J Comp Physiol A 159: 849-857

Baader A (1990) The posture of the abdomen during locust flight: regulation by steering and ventilatory interneurones. J Exp Biol 151:109-131

Baader A (1991) The contribution of some neck and abdominal motoneurones in locust (Locusta migratoria) steering reactions. J Insect Physiol 37: 689-697

Bacon J, Moehl B (1983) The tritocerebral commissure giant (TCG) wind-sensitive interneuron in the locust. I. Its activity in straight flight. J Comp Physiol 150: 439-452 
Boehm H, Schildberger K (1992) Brain neurons involved in the control of walking in the cricket Gryllus bimaculatus. J Exp Biol:166: 113-130

Boehm H, Schildberger K, Huber F (1991) Visual and acoustic course control in the cricket Gryllus bimaculatus. J Exp Biol 159: $235-248$

Borst A, Egelhaaf M (1990) Direction selectivity of fly motionsensitive neurons is computed in a two-stage process. Proc Natl Acad Sci USA 87: 9363-9367

Boyan GS (1980) Auditory neurones in the brain of the cricket Gryllus bimaculatus (DeGeer) J Comp Physiol 140: 81-93

Boyan GS, Williams JLD (1981) Descending interneurones in the brain of the cricket. Naturwissenschaften 67: 486-487

Boyan GS, Williams JLD, Ball EE (1989) The wind-sensitive cercal receptor-giant interneurone system of the locust Locusta migratoria. I. Anatomy of the system. J Comp Physiol A 165: 495-510

Boyan G, Williams L, Meier T (1993) Organization of the commissural fibers in the adult brain of the locust. J Comp Neurol 332: $358-377$

Boyd P, Lewis B (1983) Peripheral auditory directionality in the cricket (Gryllus campestris L., Teleogryllus oceanicus Le Guillou) J Comp Physiol 153: 523-532

Brodfuehrer PD, Hoy RR (1989) Integration of ultrasound and flight inputs on descending neurons in the cricket. J Exp Biol 145: $157-171$

Brodfuehrer PD, Hoy RR (1990) Ultrasound sensitive neurons in the cricket brain. J Comp Physiol 166: 651-662

Burdohan JA, Comer CM (1996) Cellular organization of an antennal mechanosensory pathway in the cockroach, Periplaneta americana. J Neurosci 16: 5830-5843

Burrows M, Rowell CHF (1973) Connections between descending visual interneurons and metathoracic motoneurons in the locust. J Comp Physiol 85: 221-234

Camhi JG, Tom W, Volman S (1978) The escape behavior of the cockroach Periplaneta americana. II. Detection of natural predators by air displacement. J Comp Physiol 128: 203-212

Deliagina TG, Zelenin PV, Fagerstedt P, Grillner S, Orlovsky GN (2000) Activity of reticulospinal neurons during locomotion in the freely behaving lamprey. J Neurophysiol 83: 853-863

Driesang RB, Bueschges A (1996) Physiological changes in central neuronal pathways contributing to the generation of a reflex reversal. J Comp Physiol A 179: 45-57

Eaton RC, Bombardieri RA (1978) Behavioral functions of the Mauthner neuron. In: Faber DS, Korn H (eds) Neurobiology of the Mauthner cell, vol 1 Raven Press, New York, pp 221-244

Eaton RC, Lavender WA, Wieland CM (1982) Alternative neural pathways initiate fast-start responses following lesions of the Mauthner neuron in goldfish. J Comp Physiol 145: 485-496

Eaton RC, Nissanov J, Wieland CM (1984) Differential activation of Mauthner and non-Mauthner startle circuits in the zebrafish: implications for functional substitution. J Comp Physiol A 155: 813-820

Egelhaaf M, Borst A, Warzecha AK, Flecks S, Wildemann A (1993) Neural circuit tuning fly visual neurons to motion of small objects. II. Input organization of inhibitory circuit elements revealed by electrophysiological and optical recording techniques. J Neurophysiol 69: 340-351

Erickson RP (1963) Sensory neural patterns and gustation. In: Zotterman Y (ed) Olfaction and taste, vol 1. Pergamon Press, Oxford, pp 205-213

Gabbiani F, Krapp HG, Laurent G (1999) Computation of object approach by a wide-field, motion-sensitive neuron. J Neurosci 19: $1122-1141$

Gebhardt M, Honegger H-W (1997) Giant descending antennalmechanosensory brain interneurons in crickets. In: Elsner N, Wässle H (eds) Proceedings of the 25th Goettingen Neurobiology Conference, vol II. Thieme, Goettingen, pp 254

Georgopoulos AP (1991) Higher order motor control. Annu Rev Neurosci 14: 361-377

Georgopoulos AP (1996) Arm movements in monkeys: behavior and neurophysiology. J Comp Physiol A 179: 603-612
Georgopoulos AP, Schwartz AB, Kettner RE (1986) Neural population coding of movement direction. Science 233: 1416-1419

Gilbert C, Strausfeld NJ (1991) The functional organization of malespecific visual neurons in flies. J Comp Physiol 169: 395-411

Goodman CS (1976) Anatomy of the ocellar interneurons of acridid grasshoppers. I. The large interneurons. Cell Tissue Res 175: $183-202$

Grillner S (1975) Some aspects on the descending control of the spinal circuits generating locomotor movements. In: Herman RM, Grillner S, Stein PSG, Stuart DG (eds) Neural control of locomotion, vol 1. Plenum Press, New York, pp 351-373

Grillner S, Wallén P (1984) How does the lamprey central nervous system make the lamprey swim? J Exp Biol 112: 337-357

Grillner S, Wallén P, Brodin L (1991) Neural network generating locomotor behavior in the lamprey: circuitry transmitters membrane properties and simulation. Annu Rev Neurosci 14: $169-199$

Griss C, Rowell CHF (1986) Three descending interneurons reporting deviation from course in the locust. I. Anatomy. J Comp Physiol A 158: 765-774

Gronenberg W, Strausfeld NJ (1991) Descending pathways connecting the male-specific visual system of flies to the neck and flight motor. J Comp Physiol A 169: 413-426

Gronenberg W, Strausfeld NJ (1992) Premotor descending neurons responding selectively to local visual stimuli in flies. J Comp Neurol 316: 87-103

Gronenberg W, Milde JJ, Strausfeld NJ (1995) Oculomotor control in calliphorid flies: organization of descending neurons to neck motor neurons responding to visual stimuli. J Comp Neurol 361: $267-284$

Harris-Warrick RM, Baro DJ, Coniglio LM, Johnson BR, Levini RM, Peck JH, Zhang B (1997) Chemical modulation of crustacean stomatogastric pattern generator networks. In: Stein PG, Grillner S, Selverston AI, Stuart DG (eds) Neurons, networks, and motor behavior. MIT Press, Cambridge, MA, pp 209-215

Hassenstein B, Reichardt W (1956) Systemtheoretische Analyse der Zeit-, Reihenfolgen- und Vorzeichenauswertung bei der Bewegungsperzeption des Ruesselkaefers Chlorophanus. Z Naturforsch 11b: $513-524$

Hedwig B (1986) On the role in stridulation of plurisegmental interneurons of the acridid grasshopper Omocestus viridulus L. I. Anatomy and physiology of descending cephalothoracic interneurons. J Comp Physiol A 158: 413-427

Hedwig B (1994) A cephalothoracic command system controls stridulation in the acridid grasshopper Omocestus viridulus L. J Neurophys 72: 2015-2025

Hedwig B (1996) A descending brain neuron elicits stridulation in the cricket Gryllus bimaculatus (de Geer) Naturwissenschaften 83: 428-429

Hedwig B (2000) Control of cricket stridulation by a command neuron: efficiacy depends on behavioral state. J Neurophysiol 83: 712-722

Hedwig B, Heinrich R (1997) Identified descending brain neurons control different stridulatory motor patterns in an acridid grasshopper. J Comp Physiol A 180: 285-294

Hensler K (1988) The pars intercerebralis neurone PI(2)5 of locusts: Convergent processing of inputs reporting head movements and deviations from straight flight. J Exp Biol 140: $511-533$

Hensler K (1992a) Intracellular recordings from intact locusts flying under closed-loop visual conditions. J Exp Biol 168: $301-306$

Hensler K (1992b) Neuronal co-processing of course deviation and head movements in locusts. I. Descending deviation detectors. J Comp Physiol A 171: 257-271

Hensler K, Rowell CHF (1990) Control of optomotor responses by descending deviation detector neurones in intact flying locusts. J Exp Biol 149: 191-205

Hoerner M (1992) Wind-evoked escape running of the cricket Gryllus bimaculatus. II. Neurophysiological analysis. J Exp Biol 171: $215-245$ 
Hoerner M, Gras H (1985) Physiological properties of some descending neurons in the cricket brain. Naturwissenschaften 72: $603-604$

Homberg U (1994a) Distribution of neurotransmitters in the insect brain. In: Rathmayer W (ed) Progress in zoology (Fortschritte der Zoologie) vol 40. Fischer, Stuttgart, pp 1-88

Homberg U (1994b) Flight-correlated activity changes in neurons of the lateral accessory lobes in the brain of the locust Schistocerca gregaria. J Comp Physiol A 175: 597-610

Horikawa K, Armstrong WE (1988) A versatile means of intracellular labeling: injection of biocytin and its detection with avidin conjugates. J Neurosci Method 25: 1-11

Horseman BG, Gebhardt MJ, Honegger HW (1997) Involvement of the suboesophageal and thoracic ganglia in the control of antennal movements in crickets. J Comp Physiol A 181: 195-204

Horseman G, Huber F (1994a) Sound localisation in crickets. I. Contralateral inhibition of an ascending auditory interneuron (AN1) in the cricket Gryllus bimaculatus. J Comp Physiol A 175: 389-398

Horseman G, Huber F (1994b) Sound localisation in crickets. II. Modelling the role of a simple neural network in the prothoracic ganglion. J Comp Physiol A 175: 399-413

Hoy RR (1989) Startle, categorial response, and attention in acoustic behavior of insects. Annu Rev Neurosci 12: 355-375

Kanzaki R, Arbas EA, Hildebrand JG (1991) Physiology and morphology of descending neurons in the pheromone-processing olfactory pathways in the male moth Manduca sexta. J Comp Physiol A 169: 1-14

Kien $\mathbf{J}$ (1983) The initiation and maintenance of walking in the locust: an alternative to the command concept. Proc R Soc Lond Ser B 219: 137-174

Kupferman I, Brezina V, Cropper EC, Deodhar D, Probst WC, Rosen SC, Vilim FS, Weiss KR (1997) Reconfiguration of the peripheral plant during various forms of feeding behaviors in the mollusc Aplysia. In: Stein PG, Grillner S, Selverston AI, Stuart DG (eds) Neurons, networks, and motor behavior. MIT Press, Cambridge, MA, pp 217-222

Kupfermann I, Weiss KR (1978) The command neuron concept. Behav Brain Sci 1: 3-39

Layne J, Land M, Zeil J (1997) Fiddler crabs use the visual horizon to distinguish predators from conspecifics: a review of the evidence. J Mar Biol Assoc UK 77: 43-54

Madsen BM, Miller LA (1987) Auditory input to motor neurons of the dorsal longitudinal light muscles in a noctuid moth Barathra brassicae L. J Comp Physiol A 160: 23-32

May ML, Hoy RR (1990) Leg-induced steering in flying crickets. J Exp Biol 151: 485-488

Milde JJ, Strausfeld NJ (1986) Visuo-motor pathways in arthropods. Naturwissenschsften 73: 151-154

Milde JJ, Strausfeld NJ (1990) Cluster organization and response characteristics of the giant fiber pathway of the blowfly Calliphora erythrocephala. J Comp Neurol 294: 59-75

Miles CI, May MI, Holbrook EH, Hoy RR (1992) Multisegmental analysis of acoustic startle in the flying cricket (Teleogryllus oceanicus): kinematics and electromyography. J Exp Biol 169: 19-36

Moiseff A, Pollack GS, Hoy RR (1978) Steering responses of flying crickets to sound and ultrasound: mate attraction and predator avoidance. Proc Natl Acad Sci USA 75: 4052-4056

Nolen TG, Hoy RR (1984) Initiation of behavior by single neurons: the role of behavioral context. Science 226: 992-994

Olberg RM (1986) Identified target-sensitive visual interneurons descending from the dragonfly brain. J Comp Physiol A 159: $897-840$

Olberg RM, Pinter RB (1990) The effect of mean luminance on the size selectivity of identified target interneurons in the dragonfly. J Comp Physiol A 166: 851-856

Olberg RM, Willis MA (1990) pheromone-modulated optomotor response in male gypsy moths Lymantria dispar L. Directionally selective visual interneurons in the ventral nerve cord. J Comp Physiol A 167: 707-714
Pfaffmann C (1955) Gustatory nerve impulses in rat cat and rabbit. J Neurophysiol 18: 429-440

Pflueger HJ, Elson R, Binkle U, Schneider H (1986) The central nervous organization of the motor neurones to a steering muscle in locusts. J Exp Biol 120: 403-420

Pollack GS, Hoy R (1981) Phonotaxis in flying crickets: neural correlates. J Insect Physiol 127: 41-45

Pollack GS, Hoy RR (1989) Evasive acoustic behavior and its neurobiological basis. In: Huber F, Moore TE, Loher W (eds) Cricket behavior and neurobiology Cornell University Press, Ithaca, pp 340-363

Ramirez JM (1988) Interneurones in the suboesophageal ganglion of the locust associated with flight initiation. J Comp Physiol A 162: 669-685

Ramirez J-M (1998) Reconfiguration of the respiratory network at the onset of locust flight. J Neurophysiol 80: 3137-3147

Ramirez J, Pearson K (1988) Generation of motor patterns for walking and flight in motoneurons supplying bifunctional muscles in the locust. J Neurobiol 19: 257-282

Regen J (1913) Ueber die Anlockung des Weibchens von Gryllus campestris L durch telephonisch uebertragene Stridulationslaute des Maennchens. Pfluegers Arch Eur J Physiol 155: 193-200

Reichert H, Rowell CHF (1985) Integration of nonphaselocked exteroceptive information in the control of rhythmic flight in the locust. J Neurophysiol 53: 1201-1218

Reichert H, Rowell CHF (1986) Neuronal circuits controlling flight in the locust how sensory information is processed for motor control. TINS 9: 281-283

Richard D, Preteur V, Campan R, Beugnon G, Williams L (1985) Visual interneurones of the neck connectives in Gryllus bimaculatus. J Insect Physiol 31: 407-417

Rind CF (1983a) A directionally sensitive motion detecting neurone in the brain of a moth. J Exp Biol 102: 253-271

Rind CF (1983b) The role of an identified brain neurone in mediating optomotor movements in a moth. J Exp Biol 102: 273-284

Rind FC (1990) A directionally selective motion-detecting neuron in the brain of the locust physiological and morphological characterization. J Exp Biol 149: 1-20

Rind FC, Simmons PJ (1999) Seeing what is coming: building collision-sensitive neurons. TINS 22: 215-220

Ritzmann RE, Tobias ML, Fourtner CR (1980) Flight activity initiated via giant interneurons of the cockroach: evidence for bifunctional trigger interneurons. Science 210: 443-445

Robert D, Rowell CHF (1992a) Locust flight steering. I. Head movements and the organization of correctional manoeuvres. J Comp Physiol A 171: 41-51

Robert D, Rowell CHF (1992b) Locust flight steering. II. Acoustic avoidance manoeuvres and associated head movements compared with correctional steering. J Comp Physiol A 171: 53-62

Rosentreter M, Schuermann FW (1982) Topographie und Typologie von Verbindungsneuronen zwischen Gehirn und Bauchmark bei der Grille Achaeta domesticus. Verh Dtsch Zool Ges 1982: 255

Rowell CHF (1993) Intersegmental coordination of flight steering in locusts. The Neurosciences 5: 59-66

Rowell CHF, Pearson KG (1983) Ocellar input to the flight motor system of the locust: structure and function. J Exp Biol 103: 265-288

Rowell CHF, Reichert H (1986) Three descending interneurons reporting deviation from course in the locust. II. Physiology. J Comp Physiol A 158: 775-794

Schildberger K (1984a) Multimodal interneurons in the cricket brain: properties of identified extrinsic mushroom body cells. J Comp Physiol A 154: 71-79

Schildberger K (1984b) Temporal selectivity of identified auditory neurons in the cricket brain. J Comp Physiol A 155: 171-185

Simmons P (1980a) Connexions between a movement-detecting visual interneurone and flight motoneurones of a locust. J Exp Biol 86: 87-97

Simmons P (1980b) A locust wind and ocellar brain neurone. J Exp Biol 85: 281-294 
Sparks DL, Kristan WBJ, Shaw BK (1997) The role of population coding in the control of movement. In: Stein PG, Grillner S, Selverston AI, Stuart DG (eds) Neurons, networks, and motor behavior MIT Press, Cambridge, MA, pp 21-32

Stabel J, Wendler G, Scharstein H (1989) Cricket phonotaxis: localization depends on recognition of the calling song pattern. J Comp Physiol A 165: 165-177

Staudacher EM (1994) Descending brain neurons in the walking cricket, Gryllus bimaculatus DeGeer. In: Roemer H (ed) 9th International Meeting on Insect Sound and Vibration. University of Graz, Graz, pp 80

Staudacher E (1998) Distribution and morphology of descending brain neurons in the cricket Gryllus bimaculatus. Cell Tissue Res 29: $187-202$

Staudacher E, Schildberger K (1998) Gating of sensory responses of descending brain neurones during walking in crickets. J Exp Biol 201: 559-572

Stout JF, Atkins G, Weber T, Huber F (1987) The effect of visual input on calling song attractiveness for female Acheta domesicus. Physiol Entomol 12: 135-140

Strausfeld NJ (1991) Structural organization of male-specific visual neurons in calliphorid optic lobes. J Comp Physiol 169: 379-393

Strausfeld NJ, Bassemir U, Singh RN, Bacon JP (1984) Organizational principles of outputs from dipteran brains. J Insect Physiol 30: 73-93

Strausfeld NJ, Gronenberg W (1990) Descending neurons supplying the neck and flight motor of Diptera: organization and neuroanatomical relationships with visual pathways. J Comp Neurol 302: 954-972

Taghert PH, Bastiani J, Ho RK, Goodman CS (1982) Guidance of pioneer growth cones: filopodial contacts and coupling revealed with an antibody to lucifer yellow. Dev Biol 94: 391-399

Thorson J, Weber T, Huber F (1982) Auditory behavior of the cricket. II. Simplicity of calling-song recognition in Gryllus and anomalous phonotaxis at abnormal frequencies. J Comp Physiol 146: 361-378
Trimarchi JR, Schneiderman AM (1995a) Different neural pathways coordinate Drosophila flight initiations evoked by visual and olfactory stimuli. J Exp Biol 198: 1099-1104

Trimarchi JR, Schneiderman AM (1995b) Flight initiations in Drosophila melanogaster are mediated by several distinct motor patterns. J Comp Physiol A 176: 355-364

Trimarchi JR, Schneiderman AM (1995c) Initiation of flight in the unrestrained fly, Drosophila melanogaster. J Zool (Lond) 235: $211-222$

Warzecha AK, Egelhaaf M, Borst A (1993) Neural circuit tuning fly visual neurons to motion of small objects. I. Dissection of the circuit by pharmacological and photoinactivation techniques. J Neurophysiol 69: 329-339

Weber T, Atkins G, Stout JF, Huber F (1987) Female Acheta domesticus track acoustical and visual targets with different walking modes. Physiol Entomol 12: 141-147

Wendt B, Homberg U (1992) Immunocytochemistry of dopamine in the brain of the locust Schistocerca gregaria. J Comp Neurol 321: $387-403$

Williams JLD (1975) Anatomical studies of the insect central nervous system: a ground-plan of the midbrain and an introduction to the central complex in the locust Schistocerca gregaria (Orthoptera) J Zool (Lond) 176: 67-86

Xin Y, Weiss KR, Kupfermann I (1996) An identified interneuron contributes to aspects of six different behaviors in Aplysia. J Neurosci 16: 5266-5279

Ye S, Comer CM (1996) Correspondence of the escape-behavior with activity of descending mechanosensory interneurons in the cockroach, Periplaneta americana. J Neurosci 16: 5844 5853

Zeiner R, Tichy H (1998) Combined effects of olfactory and mechanical inputs in antennal lobe neurons of the cockroach. J Comp Physiol A 182: 467-473 